\title{
A residência do arquiteto: uma análise gráfica das casas de Vilanova Artigas
}

\section{Ana Karla Olimpio Pereira}

Mestranda em Arquitetura e Urbanismo no Instituto de Arquitetura e Urbanismo de São Carlos da Universidade de São Paulo, Avenida Trabalhado São-Carlense, 400, Centro, CEP 13566-590, São Carlos, SP, Brasil, anakarla.op@gmail.com

\section{Paulo Yassuhide Fujioka}

Arquiteto, doutor em Arquitetura e Urbanismo pela Universidade de São Paulo, professor doutor do Curso de Arquitetura e Urbanismo do Instituto de Arquitetura e Urbanismo de São Carlos da Universidade de São Paulo, Av. Avenida Trabalhador São-Carlense, 400, Centro, CEP 13566-590, São Carlos, SP, Brasil, (16) 3373-9289, pfujioka@sc.usp.br

\begin{abstract}
Resumo
Este artigo apresenta uma abordagem sobre a questão particular na já largamente estudada arquitetura de Vilanova Artigas: as casas foram projetadas para si. A pequena escala desses projetos nos permite compreender o universo projetual do arquiteto no momento histórico de sua concepção. Estas casas foram estudados por meio de um método específico para análise gráfica de arquitetura, baseado na obra de Geoffrey Baker, Simon Unwin, Roger Clark, Michael Pause, etc.; explorando não só diagramas em 2 dimensões, mas a modelagem 3D também, a fim de entender melhor os conceitos de design do arquiteto.
\end{abstract}

Palavras-chave: análise gráfica de projeto, Artigas residências, casa do arquiteto.

residência unifamiliar, no imaginário brasileiro, é um dos bens mais caros a seus possuidores, uma vez que envolve conceitos múltiplos que variam das necessidades básicas aos anseios pessoais e também passando pelo status social. Sendo assim o arquiteto, ao projetar uma residência se depara com o grande desafio de sintetizar as expectativas e normativas impostas pelo cliente.

Ainda assim este tema de projeto constitui um campo fecundo de experimentação do profissional de arquitetura, pois as complexas relações sócioideológicas implícitas na questão da habitação unifamiliar, aliadas a um programa simplificado, possibilitam inúmeras soluções técnicas e projetuais, muitas vezes inusitadas. Ao projetar sua própria residência, o arquiteto tem uma rara oportunidade de inovação espacial, construtiva, expressiva e urbanística - através da liberdade formal e programática deste momento peculiar em que o arquiteto é projetista e cliente ao mesmo tempo.

Considerando a obra integral de Vilanova Artigas, vemos nas residências, projetadas para sua família, um retrato particular das inquietações que o moviam, em particular nesses momentos específicos de sua carreira e de sua vida. Primeiro com uma pequena casa para o casal, onde prevalece uma influência wrightiana e, depois em sua segunda residência, as influências de Le Corbusier e Oswaldo Bratke em uma habitação para a família com filhos.

O método desenvolvido para análise envolve elementos distintos de diferentes vertentes de representação e análise gráfica, levando em consideração itens como equilíbrio, iluminação, circulação, etc. e tem por objetivo especular sobre o processo de concepção dos projetos. 


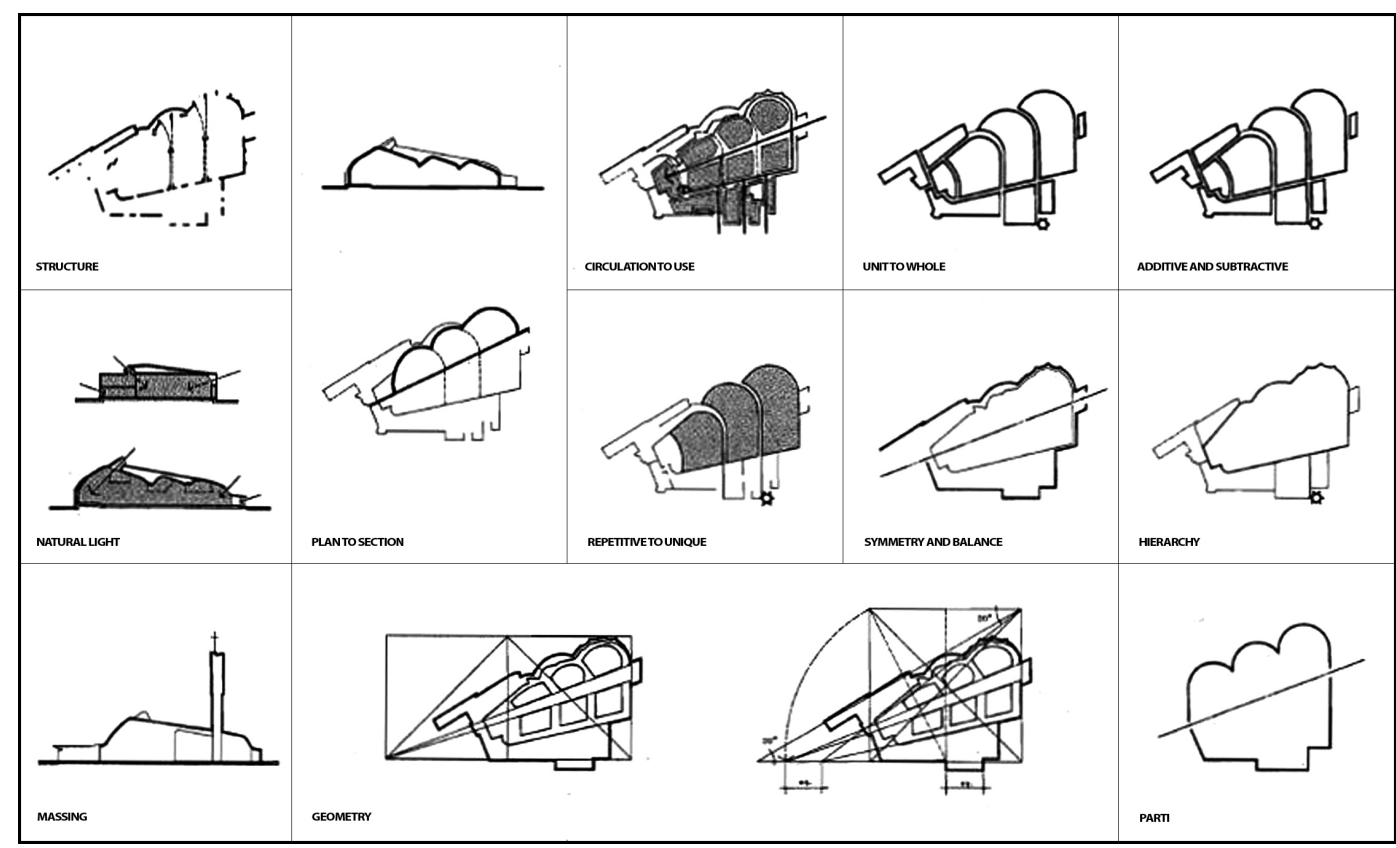

Figura 1: Vuoksenniska Church, Alvar Aalto, análise. Fonte: Clark e Pause, Hoboken, 2005, p.11

\section{Metodologia de análise}

A metodologia utilizada para análise das residências foi baseada na obras dos autores Clark e Pause (1987), Geoffrey H. Baker (1998) e Simon Unwin (2013). Os autores citados, iniciam suas análises por meio das plantas e cortes do projeto tendo como primeira abordagem o olhar direto sobre o mesmo.

"Os exemplos são, em geral, apresentados em planta ou corte, nos quais as ideias básicas e estratégias conceituais costumam ficar mais evidentes. As plantas e secções tendem a ser abstração por meio da qual os arquitetos mais projetam. Com frequência, também são o meio mais apropriado para análise. " (UNWIN, Porto Alegre, 2013 p.04)

Nesse trabalho iniciamos a análise com um levantamento de peças gráficas sobre a obra plantas, cortes, elevações e fotografias. Como também dados relevantes sobre a construção e seu estado de conservação, o conjunto de fotografias apresentado busca destacar elementos importantes na compreensão do projeto e suas leituras.

A partir disso, os primeiros elementos a serem analisados foram circulação, iluminação, estrutura, simetria, composição e hierarquia, os mesmos utilizados por Clark e Pause em seu estudo Precedents In Architecture - Analytic Diagrams, Formative Ideas, and Partis, com adição do programa que não é destacado pelos autores, mas que para a compreensão do projeto de Artigas é bastante relevante. Os autores justapõe suas análises afim de formar um painel onde podem ser vistas de forma conjunta; nesse estudo essas leituras estão agrupadas duas a duas afim de reforçar a relação intima que esses elementos estabelecem no projeto arquitetônico.

Complementando o método de Clark e Pause, os autores Simon Unwin e Geofrey Baker foram de fundamental importância pois destacam a importância de flexibilizar as análises de acordo com as particularidades do projeto e que é importante abordar temas como a geometria ideal.

"As obras de arquitetura projetadas com auxilio da geometria ideal parecem ter uma harmonia satisfatória e uma noção do que é certo; ou, no mínimo, oferecem a possibilidade de 'erro' - partes que não seguem a disciplina imposta pela geometria." (UNWIN, Porto Alegre, 2013 p.149) 
Assim como também abordam questões relativas a condições impostas pelo lugar, que Baker chama de "forças do lugar".

"Este principio de crescimento, no qual os organismos adquirem sua forma de acordo com as forças que o circundam, tem uma semelhança com o modo como a forma arquitetônica resulta em parte da resolução de um problema particular, mas também das forças características do contexto em que está situada. Edifícios se relacionam com seu entorno da maneira mais positiva, levando em conta fatores tais como uma vista, a posição do sol ou a proximidade com de uma via. Os fatores do lugar tais como uma colina ou um vale, um rio ou uma estrada, poder ser considerados como forças e, como tal, atuam direta ou indiretamente na forma." (BAKER, São Paulo, 1998 p.04)

A elaboração de modelo eletrônico da edificação auxiliou na visualização de relações volumétricas, de geometria ideal e relação com o lote, além de reforçar as relações primeiras de circulação, iluminação, estrutura, simetria, composição e hierarquia que geram uma apreensão muito maior ao serem vistas como volumes e como um todo. Observar as questões volumétricas no modelo é algo que se difere tanto da experiência espacial de adentrar ou ver fotografias do edifício quanto das análises em plantas e corte, uma vez que é possível contempla-lo como um todo e apreender as proposições de forma simultânea.

\section{A carreira como arquiteto e suas casas nesse contexto}

Formado na Escola Politécnica em 1937, Artigas associou-se com o colega de turma Duílio Marone formando a Marone \& Artigas Engenheiros, parceria que durou até 1944. Ainda em 1940, Artigas inicia carreira acadêmica na Politécnica, a convite do Prof. Anhaia Mello, como seu assistente na cadeira de Composição Geral e Estética. Em 1945, como Secretário-Geral do IAB-SP, tem participação crucial na organização do I Congresso Brasileiro de Arquitetos; e também se filia ao Partido Comunista Brasileiro, que desfrutava então de um breve período de legalidade (que duraria até meados de 1947), após a queda do Estado Novo e o fim da II Guerra Mundial (1939-45). Ainda em 1947, é aceito como bolsista da Guggenheim Foundation. A célebre viagem de estudos com o objetivo de conhecer a arquitetura e o ensino da arquitetura nos EUA é resultado desta bolsa.

Em 1948, Vilanova Artigas junta-se ao grande grupo de artistas, intelectuais e arquitetos vinculados ao IAB que fundam o Museu de Arte Moderna de São Paulo; e desenha o projeto de sede do MAM na Rua 7 de Abril. Sempre conectado com as artes visuais, o jovem arquiteto já tinha tomado contato com o conjunto de artistas do grupo Santa Helena desde 1936, através do curso noturno de desenho da Escola de Belas-Artes de São Paulo, ainda antes de se formar engenheiro-arquiteto.

Em junho de 1948, completa-se a criação da Faculdade de Arquitetura e Urbanismo da Universidade de São Paulo, desmembrando-se a formação de arquiteto da Escola Politécnica, ainda sob liderança de Anhaia Mello, seu primeiro diretor. Artigas, até então professor da Poli, torna-se também um dos membros fundadores da nova escola. Em 1949 torna-se membro do conselho de redação da revista Fundamentos, ligado ao PCB. Viaja à União soviética em 1953-54, com uma delegação de intelectuais em campanha pela paz mundial. Tal como Frank Lloyd Wright na década de 1930, volta um pouco decepcionado com a arquitetura praticada na URSS, mas sob outro ponto e vista: o da coerência entre os sentidos estético e político da arquitetura (v. Kamita, 2000, p. 122). Participa do concurso nacional para o Plano Piloto de Brasília-DF em 1956, em equipe com Paulo Camargo e Almeida, Mário Wagner Vieira da Cunha e Carlos Cascaldi (obtendo o quinto lugar).

É dentro deste contexto histórico que se inserem os projetos de residência do arquiteto. A produção de Artigas pode ser dividida em três fases (Kamita, pp. 9-12). A primeira foi caracterizada pela intensa produção no escritório Marone \& Artigas, na Rua São Bento 484, que abrangeu cerca de 200 projetos entre 1937 e 1944. Esta fase primordial foi pouco comentada e divulgada pelo próprio Artigas, compondo-se na maior parte por residências unifamiliares. Apesar de notoriamente conhecida como uma "fase wrightiana", grande parte dessas obras segue o historicismo exigido pela clientela da época. Esta fase poderia ser melhor definida como um período de aprendizado prático de projetista e construtor, ao mesmo tempo em que o arquiteto fazia 
reflexão sobre as contradições e conflitos ideológicos do ofício. (Kamita, pp. 9-12; Fujioka, 2004, p. 216).

Em Wright e Artigas - Duas Viagens (2002), Adriana Irigoyen faz uma análise reveladora deste período (pp. 128-146). Os projetos mais interessantes desta fase, todos em São Paulo, são a casa Berta Gift Stirmer (1940), a Casa Roberto Lacaze (1941), a "Casinha" Vilanova Artigas (1942), a Casa Rio Branco Paranhos (1943) e a Casa Rivadávia de Mendonça(1944) - em que é possível constatar uma evolução paulatina e virtuosística da inspiração wrightiana (Fujioka, 2004, pp. 217-222).

A segunda fase inicia-se por vota de 1944, quando Kamita distingue em Artigas um redirecionamento em favor do racionalismo corbusiano (p. 13-24). Também é possível distinguir outras influências, como a do antigo mestre Oswaldo Bratke e da Escola Carioca. Trata-se de um novo período de experimentação, com espaços livres e fluidos, com generosa iluminação, preparatórios para fase da Escola Paulista. A ampliação da "Casinha" original (1949) é um exemplo desta experimentação, que inclui a Casa Benedito Levi e o Conjunto das Quatro Casas para Jaime Porchat Queiroz Mattoso (São Paulo, 1944), o Hospital São Lucas (Curitiba, 1945), o Edifício Louveira (São Paulo, 1946), a Casa Elphy Rosenthal (São Paulo, 1946), as casas Tacques Bittencourt I e Czapski (São Paulo, 1949) a Casa Heitor de Almeida (santos, 1949), a Casa da Criança da Prefeitura e a Rodoviária de Londrina (1950).

Pode-se considerar que a terceira fase inicia-se em 1956 com a Casa Olga Baeta em São Paulo, que marca o "início da pesquisa formal após um período de conflitos" (Thomaz, 1993, p. 82, apud Fujioka, 2004, p. 217). Trata-se de um período de experimentação madura e original, com as casas José Ferreira Fernandes (1957) e Rubens de Mendonça (1958), ambas em São Paulo. Já com a Casa José Mário Tacques Bittencourt II (São Paulo, 1959), Artigas retoma ao tema arquetípico da arquitetura como abrigo, rompendo ousadamente com o sistema pilar/viga/laje em favor de uma casa-pórtico de concreto armado (estrutura como arquitetura). No mesmo ano, essa visão é levada adiante com o projeto do Ginásio de Itanhaém.

Nos anos seguintes, temos a evolução paulatina e cada vez mais ousada destes conceitos na obra de
Artigas, como nota-se nos projetos do Ginásio de Guarulhos (1960), o Vestiário do São Paulo Futebol Clube (São Paulo, 1960), a Garagem de Barcos do Santa Paula late Clube (São Paulo, 1961), o Anhembi Tênis Clube (São Paulo, 1961), a nova sede da FAUUSP (1961-68), a EEPSG 31 de Março / Ginásio de Utinga (Santo André, 1961-68) - todos estes realizados com Carlos Cascaldi.

A partir de 1966, o arquiteto produz a maioria de seus projetos sozinho, com algumas associações ocasionais, como o do Conjunto Zezinho Magalhães Prado - CECAP Cumbica (Guarulhos, 1967), projetado com Fábio Penteado, Paulo Mendes da Rocha e equipe do Escritório Técnico CECAP. Desta rica produção solo que marca a consolidação de sua forma de conceber arquitetura, vale destacar a Casa Elza Berquó (São Paulo, 1967), a Rodoviária de Jaú (1973) e a EEPG Conceiçãozinha (Guarujá, 1976), só para ficarmos em apenas três exemplos.

\section{As casas no contexto da carreira de Artigas}

Se a casa do arquiteto constitui uma oportunidade de experimentação, ainda mais se a oportunidade surge no início de sua carreira, o espírito sempre inconformado de Vilanova Artigas não deixaria de fazer de suas "casinhas" uma reflexão sobre suas inquietações em relação à arquitetura moderna. Neste fragmento de um depoimento à revista "Construção São Paulo" n. 1910, 17/09/1984, pp. 14-22, in Xavier, Depoimentos de uma geração - arquitetura moderna brasileira (2003), pp. 219220, apud Fujioka, 2004, p. 218, entrevistado por L. Pereira, Artigas afirma que:

"Encontrei em Frank Lloyd Wright uma formulação que não encontrava no curso da Poli. Por exemplo, eles ensinavam a fazer o telhado, mas dependíamos do telhadeiro que, em geral, era um operário europeu imigrante."

Perguntado sobre quais os reflexos dessas lições em seus primeiros projetos, Artigas respondeu que:

"Nos anos 40, fizemos uma revolução. Nos primeiros projetos wrightianos, decidi que eu mesmo calcularia os telhados para ver a forma que resultaria. Assim, essas casas me impuseram a disciplina de fazer 
meu projeto completo. Usei o mesmo método quando fiz os primeiros projetos de arquitetura (sic), precisamente na década de 50. Sim, porque antes não existia o projeto, mas fotografias daquilo que Le Corbusier e outros arquitetos europeus e norte-americanos haviam feito. Então, era preciso transformar aquilo em projeto. Tivemos de rever todos os detalhes, pois até aquela época tudo se fazia na base da imitação.

"A etapa seguinte foi fazer da estrutura da casa um elemento capaz de caracterizá-la: as colunas de baixo assumiram, então, a forma que elas tem e a ossatura começou afazer parte da expressão formal do projeto". (in Xavier, pp. 219-220, apud Fujioka, 2004, p. 218)

A "Casinha" é, de fato, uma experiência de programa habitacional mínimo, similar às usonian houses de Frank Lloyd Wright, do mesmo período histórico. O partido em "pinwheel plan", concebido por Wright ainda nas prairie houses, está organizado ao redor do hall. O sentido de horizontalidade wrightiano está manifesto nos beirais generosos e vazados, na fenestração e na textura da alvenaria aparente. Esta horizontalidade de planos e volumes, que parece aumentar a escala da casa, é um dos princípios da arquitetura organicista de Frank Lloyd Wright (Fujioka, 2004, pp. 39-60). Outro destes princípios, o da natureza dos materiais, está presente na estrutura exposta de madeira e na alvenaria aparente. Além disso, outras características wrightianas estão presentes, bem como as janelas de canto e a cozinha articulada ao estar/jantar, formando um espaço aberto, fluido e ancorado pelo volume da lareira. Esta articulação de espaços, a simplicidade do programa e a concentração dos espaços molhados (banheiro, cozinha e lavanderia) são soluções típicas das usonian houses (Fujioka, 2004, pp. 95-116). Em contraponto, temos também Artigas comentando a articulação cozinha/sala nestes termos:

"Transferi algumas vivências minhas, de menino paranaense, do sul do Brasil, que tem sala e não sabe para quê. A convivência da família brasileira era na cozinha. Enquanto, na casa tradicional paulista, a sala de jantar de dirigiu na direção do 'living room', pelo processo de transformar duas salas em uma, eu fui para a tradição brasileira de integrar a cozinha à sala. Segui um caminho diverso. Sei que perdi a parada. Mas a minha casa está lá" (in Vilanova Artigas, p. 36).

É interessante comparar este comentário de Artigas com o texto de Wright em The Natural House (1954) sobre a casa rural do imigrante alemão no Meio-Oeste dos EUA que este conhecia desde sua infância (v. Fujioka, 2004, pp. 98-99). A argumentação de Wright, evocando a casa de fazenda centrado num grande espaço de convivência com fogão (também, portanto, sem ambientes de estar ou jantar), apresenta um curioso paralelo com o co-mentário de Artigas. Além disso, o arquiteto faz uso de outro recurso muito utilizado por Wright nas usonian houses: criar partições entre ambientes com mobiliário embutido, ao invés de utilizar paredes portantes (Fujioka, 2004, pp. 95-116).

Artigas considera, no mesmo comentário (op. cit., p. 36), que esta casa marca uma nova fase, rompendo com as convenções tradicionais de fachada e volume. Isto está patente na implantação em ângulo com o alinhamento da rua, contestando padrões tradicionais de alinhamento de fachadas e acomodando melhor a edificação no terreno.

A construção de sua segunda residência, que fica pronta em 1949; mais arrojada e inspirada na segunda fase de Le Corbusier, o projeto destacase pelo acréscimo em área útil e pela adoção de materiais menos tradicionais como o concreto, aço e vidro. São caminhos de concepção que já eram vistos em projetos anteriores como na Casa Trostli (1948) e na Casa Czapski (1949); mas que ganham força a partir dos anos 50 .

"Ainda na década de 50 achei que era necessário mudar a tipologia da casa paulistana. Tratava-se de modificar a divisão interna espacial da casa de classe média paulista que necessitava se atualizar em relação ás modificações sociais em nosso país. Nessa época era comum as casas manterem a entrada de carro como reminiscência da antiga cocheira, com o quarto da criada e o tanque de lavar nos fundos. Para mim, elas deveriam ser pensadas como um objeto com quatro elevações, mais ou menos iguais, ajustando-se a paisagem como uma unidade." (ARTIGAS Apud FERRAZ; PUNTONI; PIRONDI; LATORRACA; ARTIGAS(Orgs.), 1997. p 26). 


\section{Primeira residência do arquiteto: "Casinha"}

A "Casinha", como Artigas a chamava, consistiu-se na rememoração da casa de sua infância no Paraná. Contava com programa reduzido que refletia a simplicidade de uma rotina familiar e social mais modesta e organizada em torno da cozinha e do quintal. Distinta portanto, da tradição colonial portuguesa onde havia forte separação entre área social e serviços. Essa tradição se mantinha no espaço da casa urbana paulistana á epoca onde o quintal era um espaço de menor importância, muitas vezes escondido e com entrada distinta da principal; uma área relegada a atividades cotidianas da residência como trabalhos domésticos e lazer das crianças, assim como a cozinha era um espaço exclusivo para empregados, mantendo no espaço da residência um resquício da tradição escravocrata.

Figura 2: Estado atual da residência. Fonte: acervo da autora.
O rompimento com esses preceitos tradicionais se inicia no programa que não inclui uma área social para visitas apartada dos ambientes sociais e de serviços que são integrados aos demais espaços. Havendo separação apenas das áreas intimas e de trabalho, pois o escritório é anexado a residência por meio de um pequeno ambiente embaixo do mezanino do quarto, algo bastante incomum a época, esses ambientes internos são delimitados por níveis e mobiliários, sem o uso de paredes como aponta CUNHA em seu artigo "A casinha de Artigas: reflexos e transitoriedade":

Essas mudanças na morfologia da casa determinam uma planta praticamente sem divisões internas, ainda que as paredes estivessem vinculadas diretamente à estrutura. Os outros elementos do programa, como dormitório e estúdio, são definidos por dois meio níveis, integrando tanto um ao outro - por meio de um pé-direito duplo - quanto à sala.

Estratégia que terá importante papel estruturador nas plantas projetadas por Artigas nos anos posteriores, setorizando os espaços de acordo com seus usos e sem o auxílio de paredes. (CUNHA, 2005)

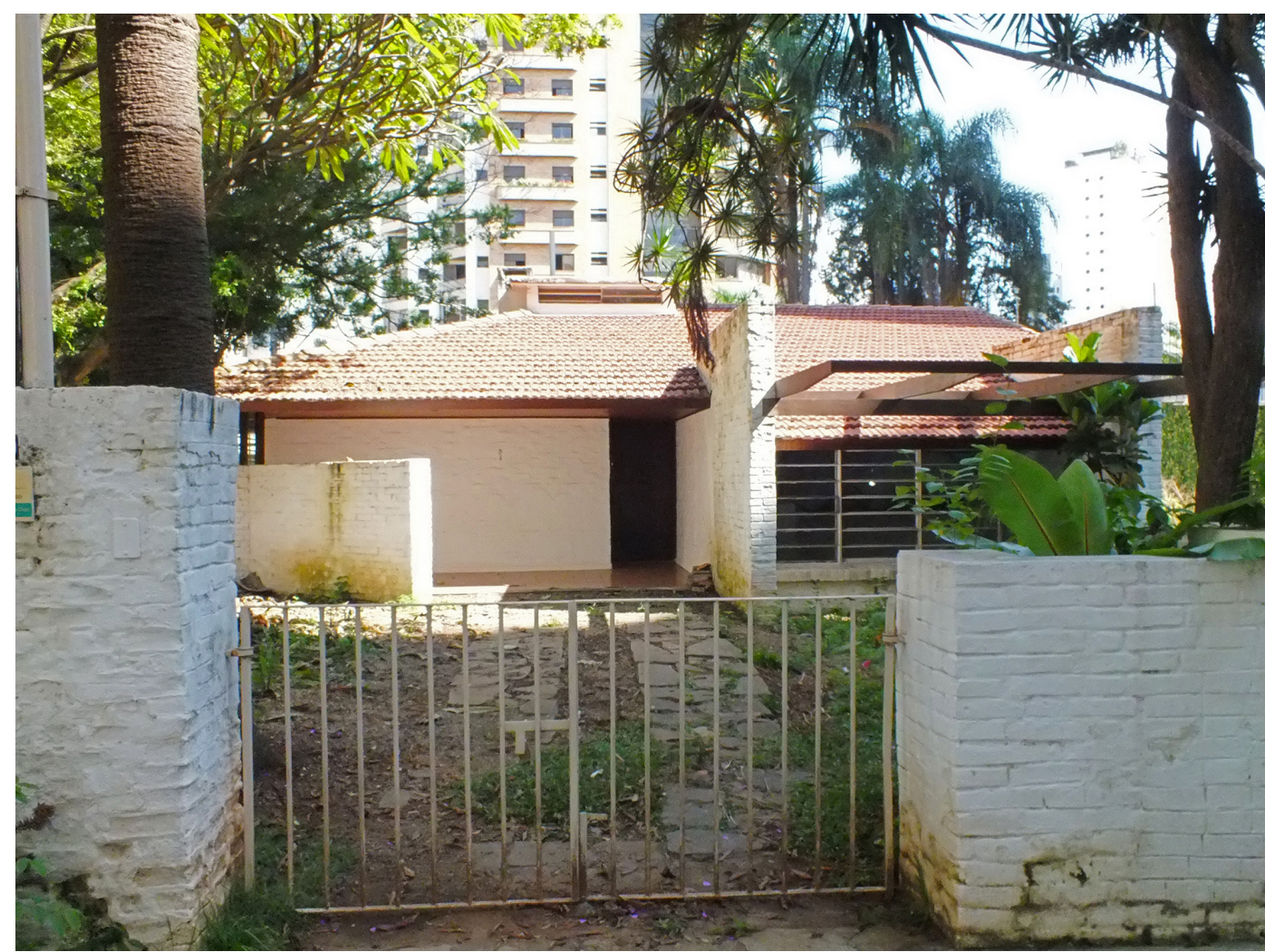


1 A propriedade está à venda pela família Artigas, que encontra dificuldade na comercialização do imóvel uma vez que a casa é patrimônio tombado e não pode ser demolida ou modificada, o que Ihe causa grande desvalorização uma vez que está localizada em meio a uma área de grande verticalização e adensamento e está sob forte pressão da especulação imobiliária. É importante apontar em imagens alguns pontos relevantes, como detalhes construtivos e de conservação.

Figuras 3 a 5: Implantação e localização. Fonte: ACAYABA, São Paulo, 1986, p36 e 38, e Google Maps.
Com isso, concluimos que isso é um posicionamento ideológico, que se traduz em espacialidade formal e coerente com seu posicionamento político, pois o uso de materiais tradicionais é uma forma de baratear o processo construtivo, importante para um arquiteto em inicio de carreira e também é uma forma de apreciar a brasilidade existente nessas relações postas no convívio da habitação uni familiar.

Dados da construção e estado atual

Construção: 1941-42

Localização: Rua Barão de Jaceguai, 1151

Proprietário: pertence a Júlio Artigas, que mora na residência ao lado.

Área do terreno: $900 \mathrm{~m}^{2}$

Área construída: $102,74 \mathrm{~m}^{2}$

Área ocupada: $102,74 \mathrm{~m}^{2}$

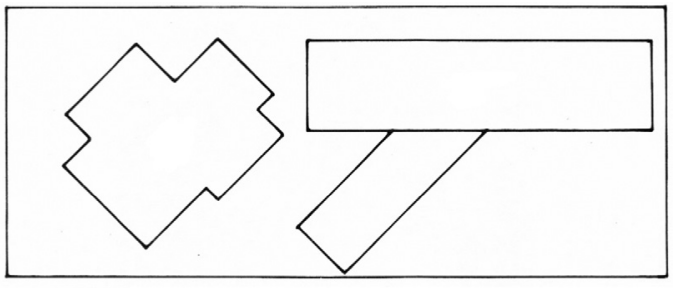

Implantação
Estado atual ${ }^{1}$ : está desocupada e necessita de reparos, já foi utilizada como loja de artigos naturais e plantas por um período, esse novo uso deixou marcas como a modificação de mobiliário e novos pontos hidráulicos. Porém, não há comprometimento aparente da estrutura e não foram feitas alterações significativas que descaracterizassem a construção.

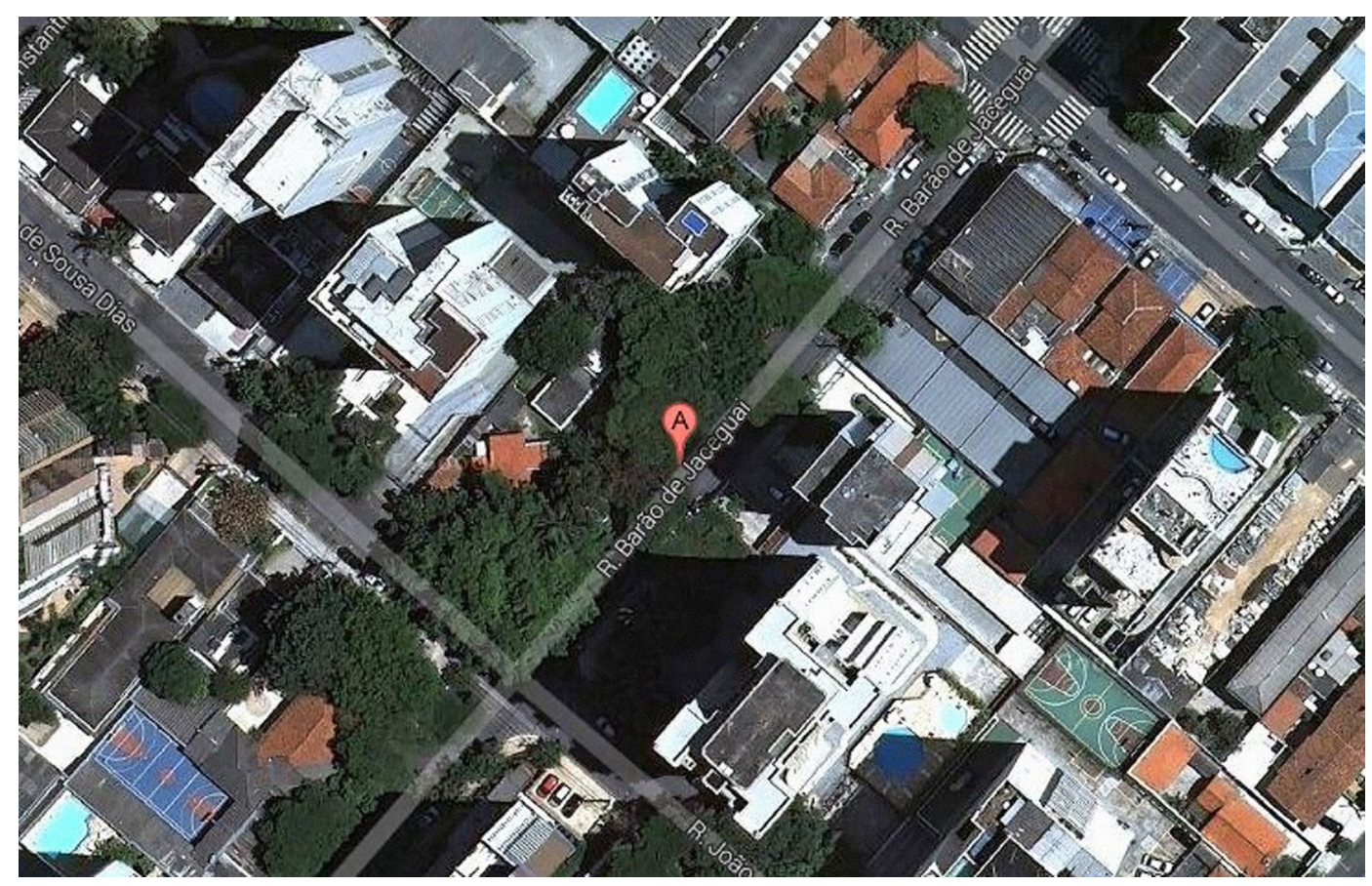



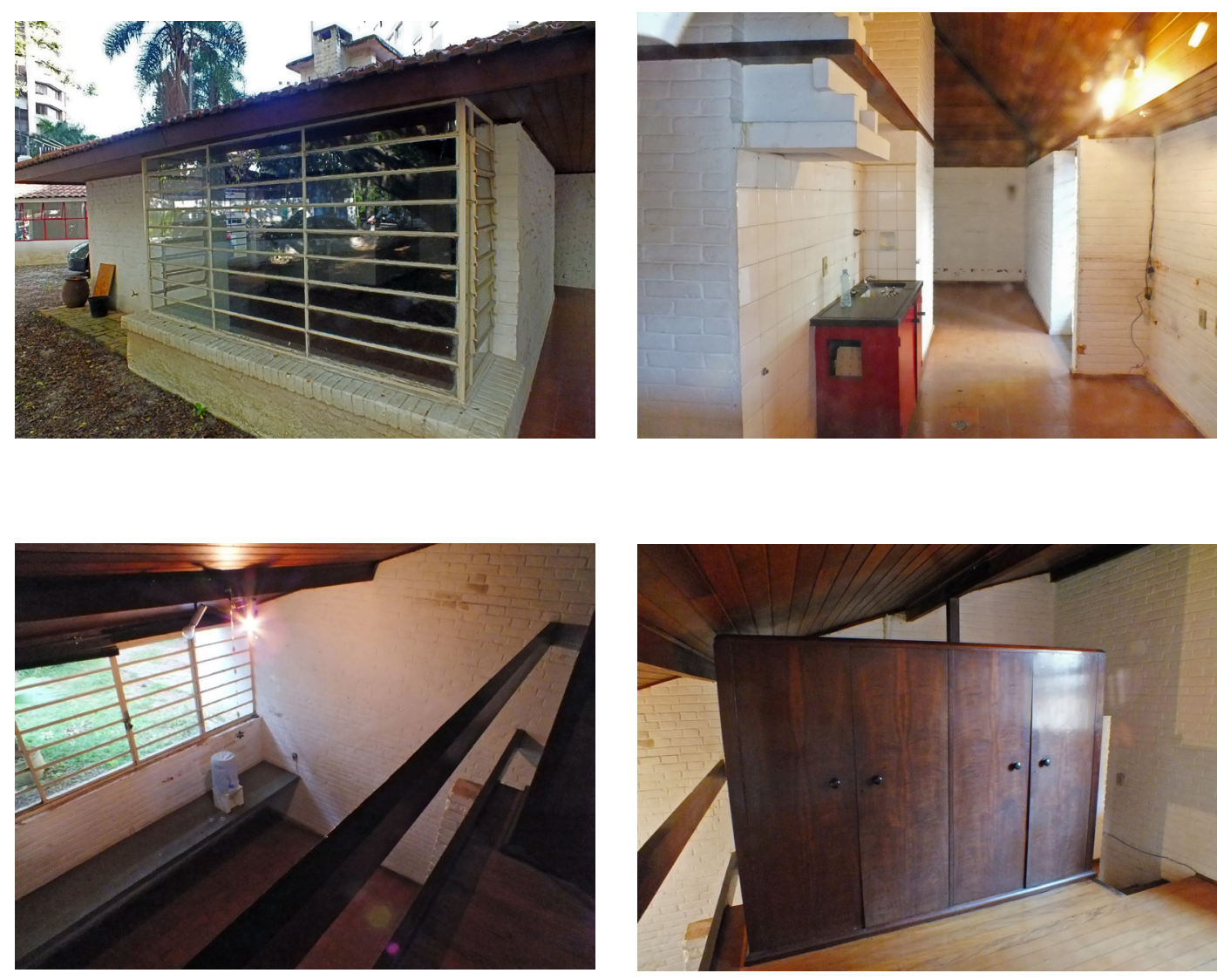

Figuras 6 e 7 (topo): Bay window, interior da cozinha, detalhe da chaminé em tijolo da cozinha. Fonte: acervo da autora.

Figuras 8 e 9 (meio): Mezzanino e divisão com mobiliário (característica wrightiana), originais do projeto. Fonte: acervo da autora.

Figuras 10 e 11 (embaixo): Detalhe das prateleiras do escritório e vista da escada originais do projeto. Fonte: acervo da autora.
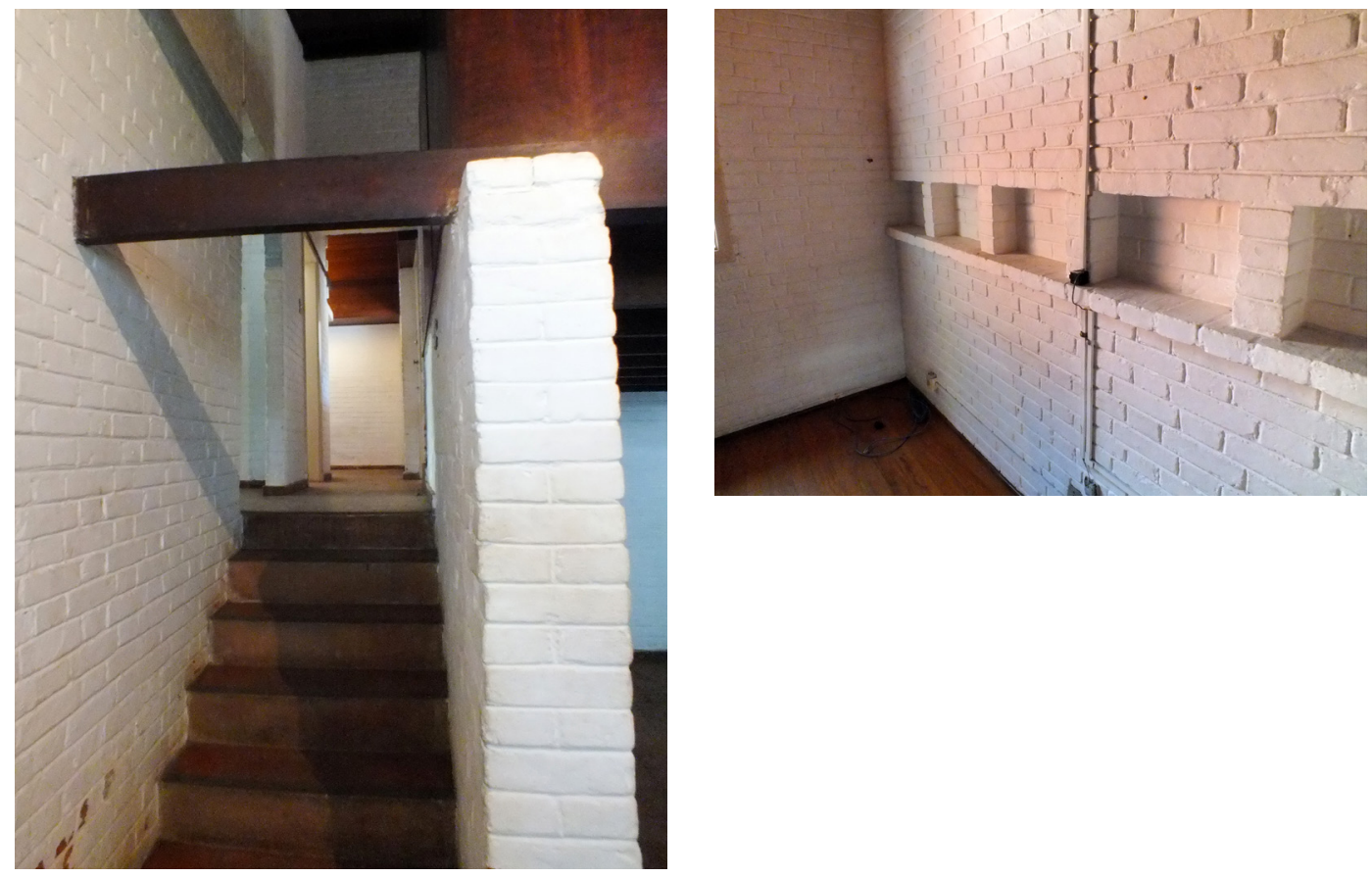
Figura 12: Planta da "Casinha" (1942). Reparar no carimbo da prancha "Marone e Artigas". Fonte: acervo Biblioteca FAU-USP.

Figura 13: Cortes e detaIhes básicos da "Casinha" (1942). Reparar no carimbo da prancha "Marone e Artigas". Fonte: acervo Biblioteca FAU-USP.

\section{Análise Gráfica}

Implantação, planta e corte

Como primeira aproximação do projeto após leitura do entorno, analisamos as plantas e cortes, onde é possível apreender a escala e implantação. De imediato o olhar é atraído, para a implantação da casa em $45^{\circ}$ em relação aos limites do lote. Isto é devido à intenção do arquiteto em desconstruir a ideia de hierarquia entre entradas e fachadas, além da adequação à insolação.

Essa implantação também se caracteriza como (Sendo o "desacordo" entre o lote e a implantação a $45^{\circ}$ da casa, nada mais do que a afirmação da atividade do arquiteto como construtor do espaço urbano, de forma inovadora e não reproduzindo o que estava dado pelo formato do lote.) (Buzzar, São Paulo, 2014, pp.306), essa implantação em rotação ou diagonal de $45^{\circ}$ em relação ao sítio é outra característica forte da arquitetura de Wright (FUJIOKA, São Paulo, 2003, pp. 106-107 e 220-221).

"A casinha é de 1942. Foi um rompimento formal meio grande. A partir dela, foi à primeira vez que fiz e tive coragem de fazer porque era para mim, me libertei inteiramente das formas que vinham vindo. Libertei-me da planta porque a cozinha passou a se integrar na sala. Marcou uma nova fase em todo tratamento volumétrico daquilo que podia se chamar fachada, porque a fachada desapareceu". (ARTIGAS Apud CUNHA, 2005).
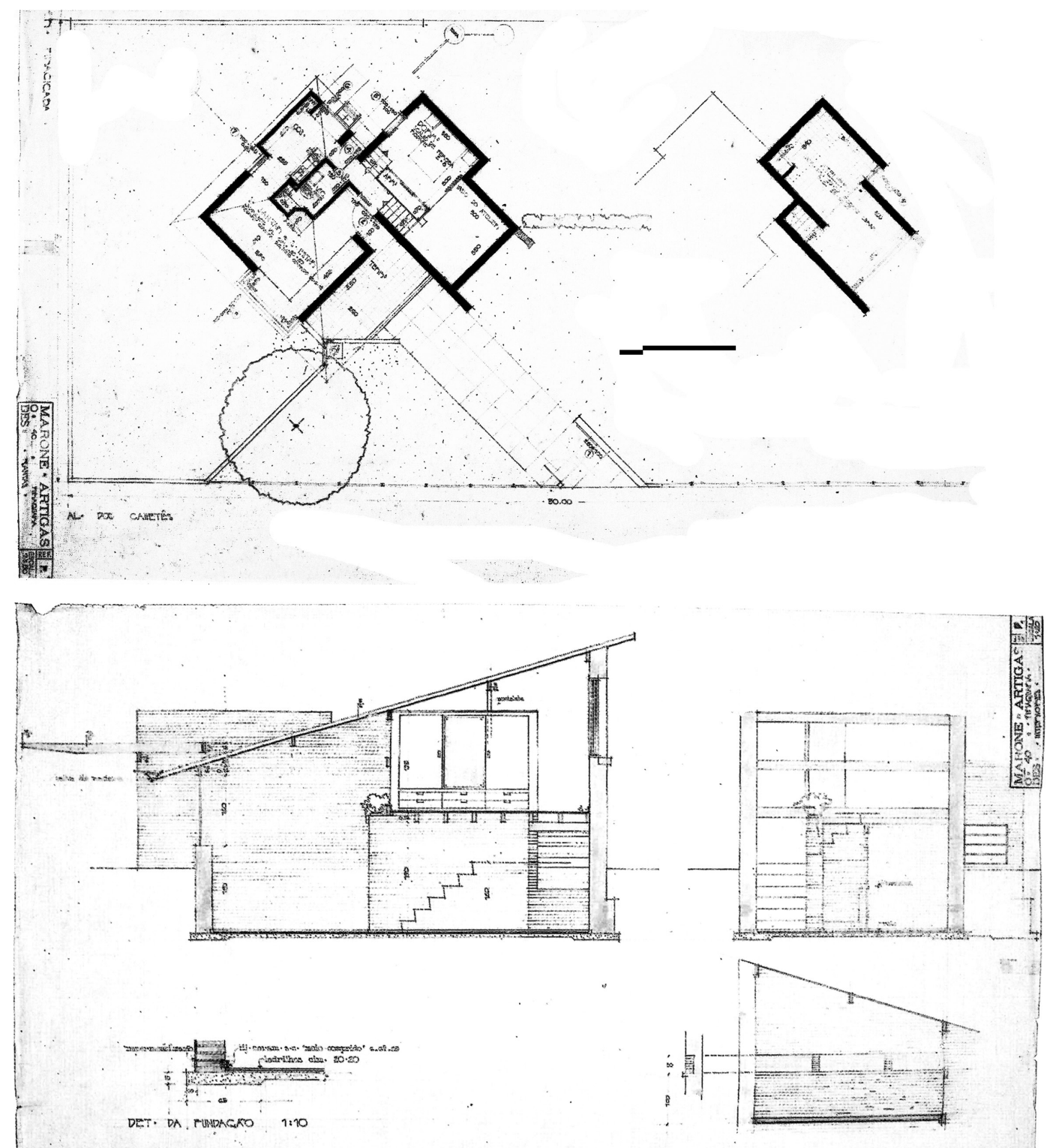
Programa, circulação, iluminação e estrutura

A área destinada a todas as funções sociais, intimas e de serviços é equivalente, excluindo o terraço que é uma área social, porém com uso reduzido por ser externa, concluímos a partir disso que o arquiteto considerava de igual importância todas as funções da habitação, não havendo espaços mais importantes do que outros, inclusive o espaço de trabalho, que excluindo a circulação possui a mesma área do dormitório.

A circulação é bastante econômica e centralizada

Figura 14: Relações gráficas 2D de programa e circulação na "Casinha". Fonte: intervenção sobre imagem de acervo Biblioteca FAU-USP. em torno do banheiro, que fica na região central da planta, de modo a ficar equidistante a qualquer usuário da casa. Também coloca entradas em faces opostas o que maximiza a circulação de pessoa e ventilação cruzada, a ventilação do banheiro é feita por meio de um pequeno lanternim. O partido remete fortemente à "planta em catavento" da arquitetura residencial de Wright (FUJIOKA, São Paulo, p. 74).

A iluminação se dá por aberturas na alvenaria em tijolo aparente, sendo apenas mais comedida na área intima, a implantação em $45^{\circ}$ auxiliou a insolação, uma vez desalinhou as faces em relação às construções de gabarito elevado do entorno, aproveitando assim a iluminação em diferentes horários. Em termos estruturais a construção e muito simples, térrea com apenas uma diferença de altura entre dois blocos compostos por grossas paredes de tijolos que sustentam o telhado convencional de telhas cerâmicas, o que minimiza os custos de construção.

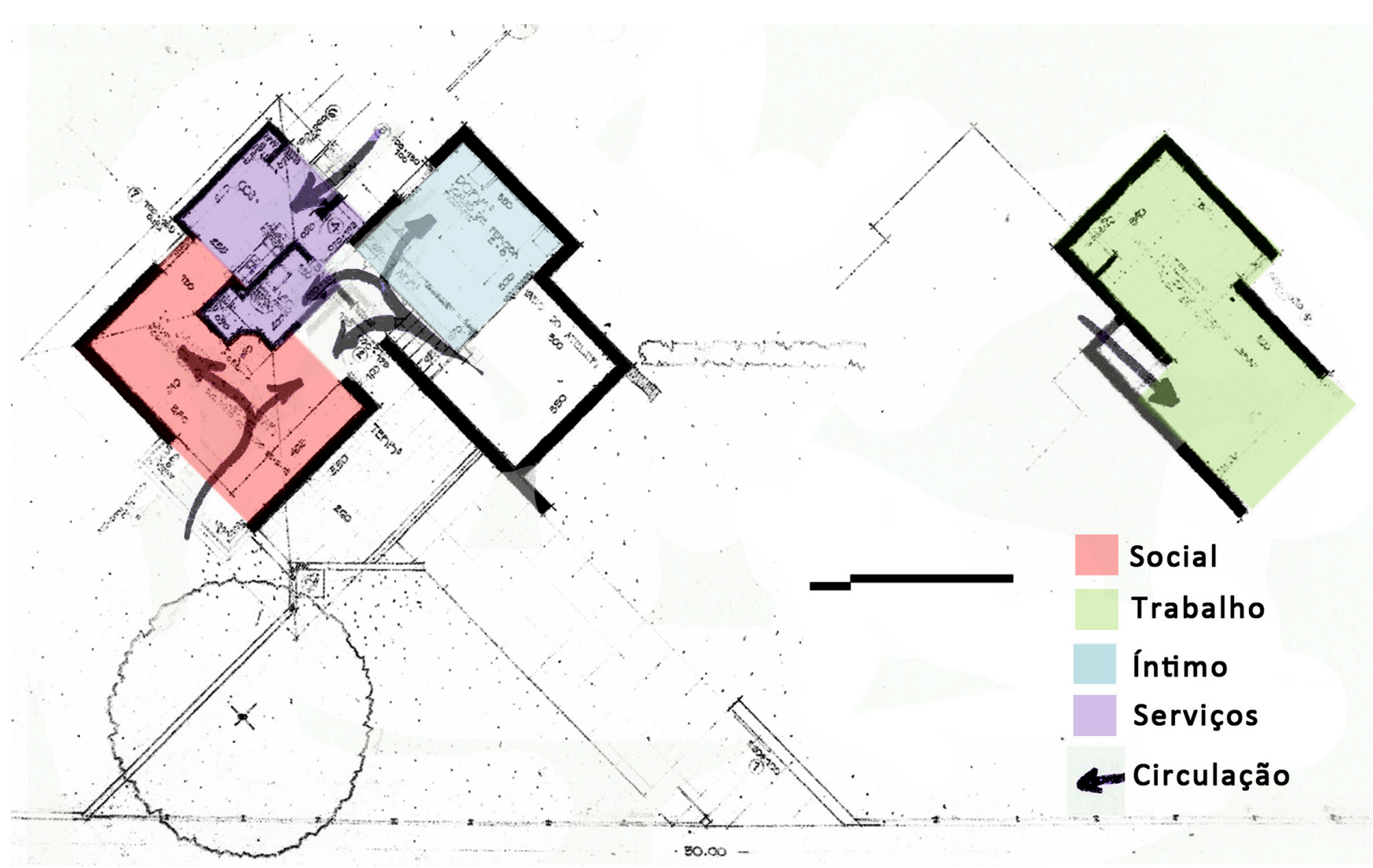


Figura 18: Relações gráficas 2D de traçado regulador, proporção e simetria na planta da "Casinha". Fonte: intervenção sobre imagem de acervo biblioteca FAU-USP.

Figura 19: Relações gráficas 2D de proporção e simetria em corte na "Casinha". Fonte: intervenção sobre imagem de acervo biblioteca FAU-USP.
Geometria ideal, proporção e equilíbrio

As proporções e relações gráficas encontradas ao analisarmos esse pequeno projeto são muito ricas, talvez por sua geometria em planta estar inserida em um quadrado (similar à de várias prairie houses, v. FUJIOKA, São Paulo, 2003, pp. 74-76) o que possibilitou muitas conexões a principio imperceptíveis; como a equivalência entre as distancias das paredes das paredes paralelas como destacado na imagem 18, onde o arco de circunferência em lilás liga a parede do ateliê, as demais paredes reforçando o rigor geométrico apresentado em todo o projeto.

Analisando o desenho em si, destacamos que a composição parece conseguida pelo arranjo de quadrados em planta e corte, que são seccionados por um retângulo em proporção áurea que compõe a área social (destacado em vermelho na imagem 18) figura que se repte na relação em corte compondo o espaço de trabalho (destacado em amarelo na Figura 19), vemos também o emprego do retângulo de ouro, soma de dois quadrados na relação entre largura e pé direito do ateliê (destacado em vermelho na Figura 19).
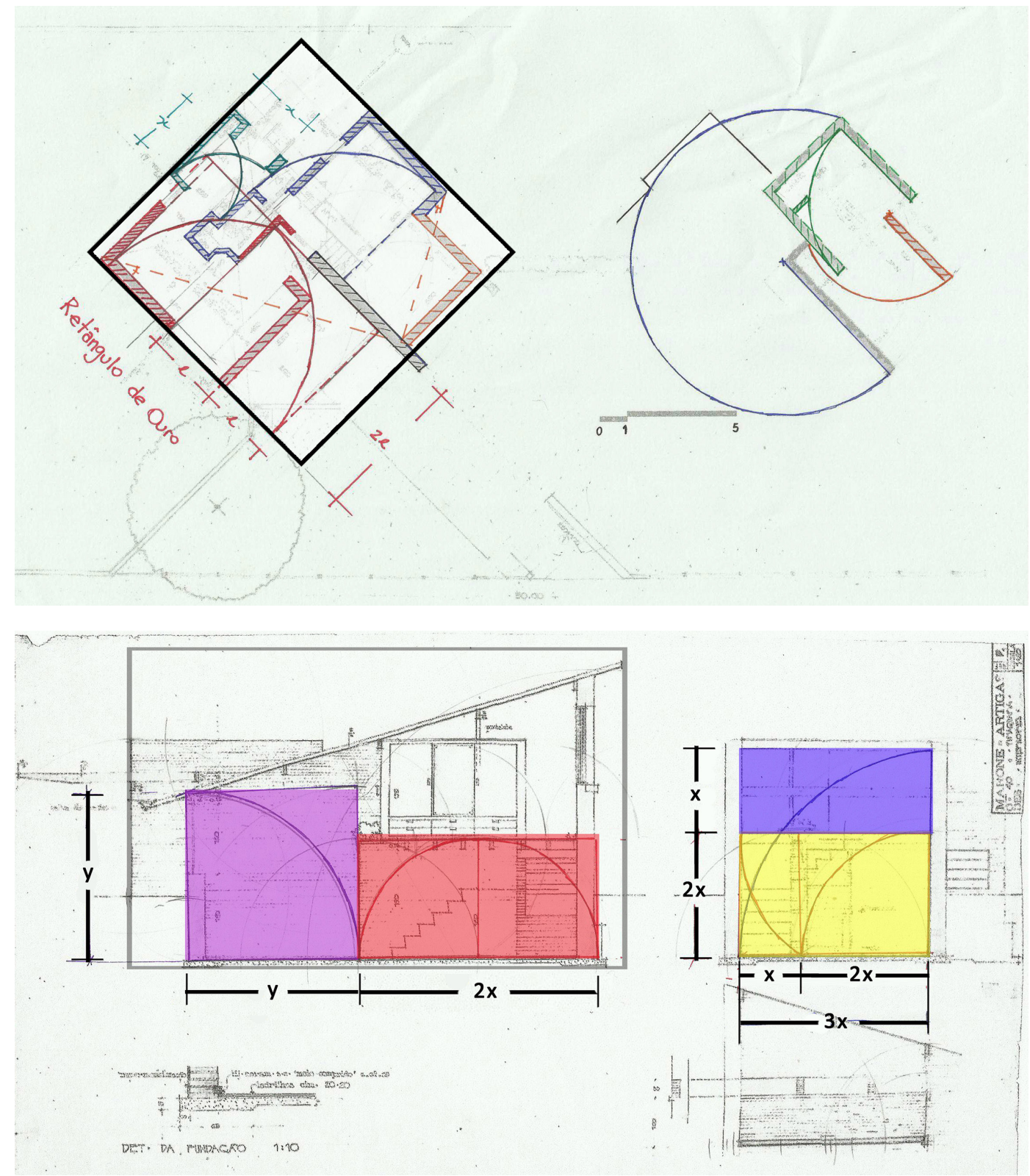


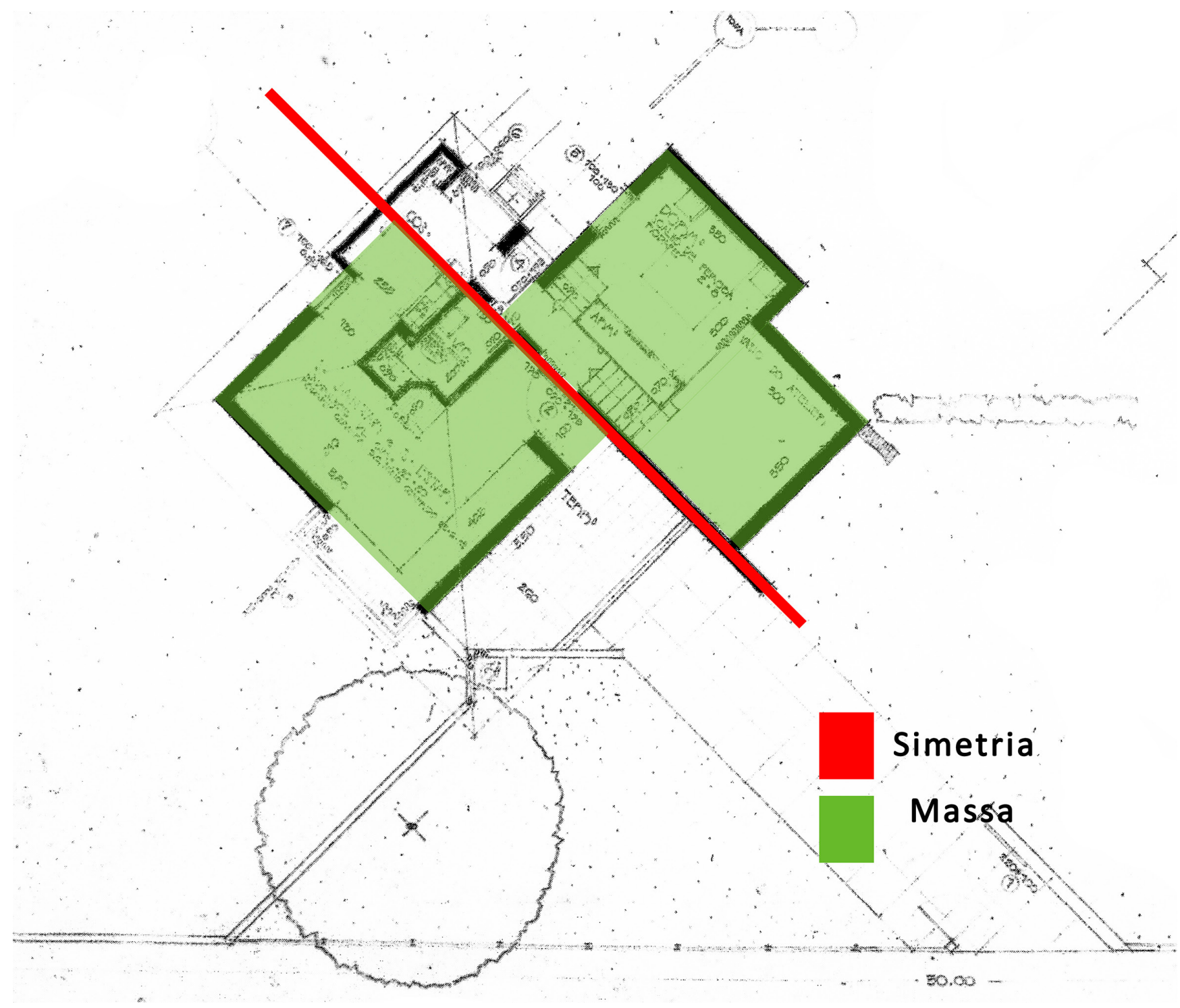

Figura 20: Relações gráficas 2D de simetria e equilíbrio de massas. Fonte: intervenção sobre imagem de acervo Biblioteca FAU-US.
Por meio das relações obtidas na análise gráfica, consideramos um cuidado formal da parte do arquiteto, além dos cuidados construtivos e que acreditamos sejam decorrentes de seu posicionamento ideológico o que transformam a obra em uma experiência arquitetônica completa, pois entendemos que existe um cuidado que vai das relações virtuais no desenho em planta ao detalhe construtivo de tijolo na iluminação zenital do sanitário.

A análise apresentada das imagens 18 a 20 mostram especulações sobre o processo de projeto a partir de sua planta e corte, que para Clark e Pause mostram um partido de composição de projeto, ou seja, uma síntese da composição projetual. 


\section{Segunda residência do arquiteto (1949)}

A nova construção desempenha um papel fundamental na carreira do arquiteto, pois marca a transição para a segunda fase, afastando-se de Wright (mas não de todo) e aproximando-se de Le Corbusier. De uma forma critica e bastante original, onde Artigas associa materiais industrializados como concreto e vidro ao tijolo aparente, um material bastante tradicional, adotando tanto elementos do novo estilo (estrutura independente, planta livre, curtain wall, abóbada catalã corbusiana) como da tradição vernacular nativa, como a lareira no centro da área social e as áreas de serviço como garagem e lavanderia em primeiro plano no acesso da residência.

Figura 21: Estado atual da Casa do Arquiteto II. Fonte: acervo da autora.
Na segunda casa de Artigas de 1949, pode-se perceber um desenvolvimento da linguagem utilizada na casa Benedito Levi, agora utilizando planos inclinados de cobertura (asa de borboleta) e expandindo os panos de vidro para os dois andares. Com relação aos materiais há o concreto armado predominando na parte superior da casa, a cobertura, no nível intermediário os panos de vidro e abaixo deles, no embasamento, paredes de tijolo a vista. (CUNHA, 2009, pp.55)

Percebe-se também ressonâncias da arquitetura de Oswaldo Bratke (1907-1997), de quem foi estagiário na construtora Bratke e Botti e com quem ainda mantinha diálogo. Pois ambos valiam-se das coberturas com estrutura em concreto, vidro e tijolo como também trabalham construções lineares e térreas de programa enxuto como casa para a família que Bratke constrói na chácara Morumbi em 1951.

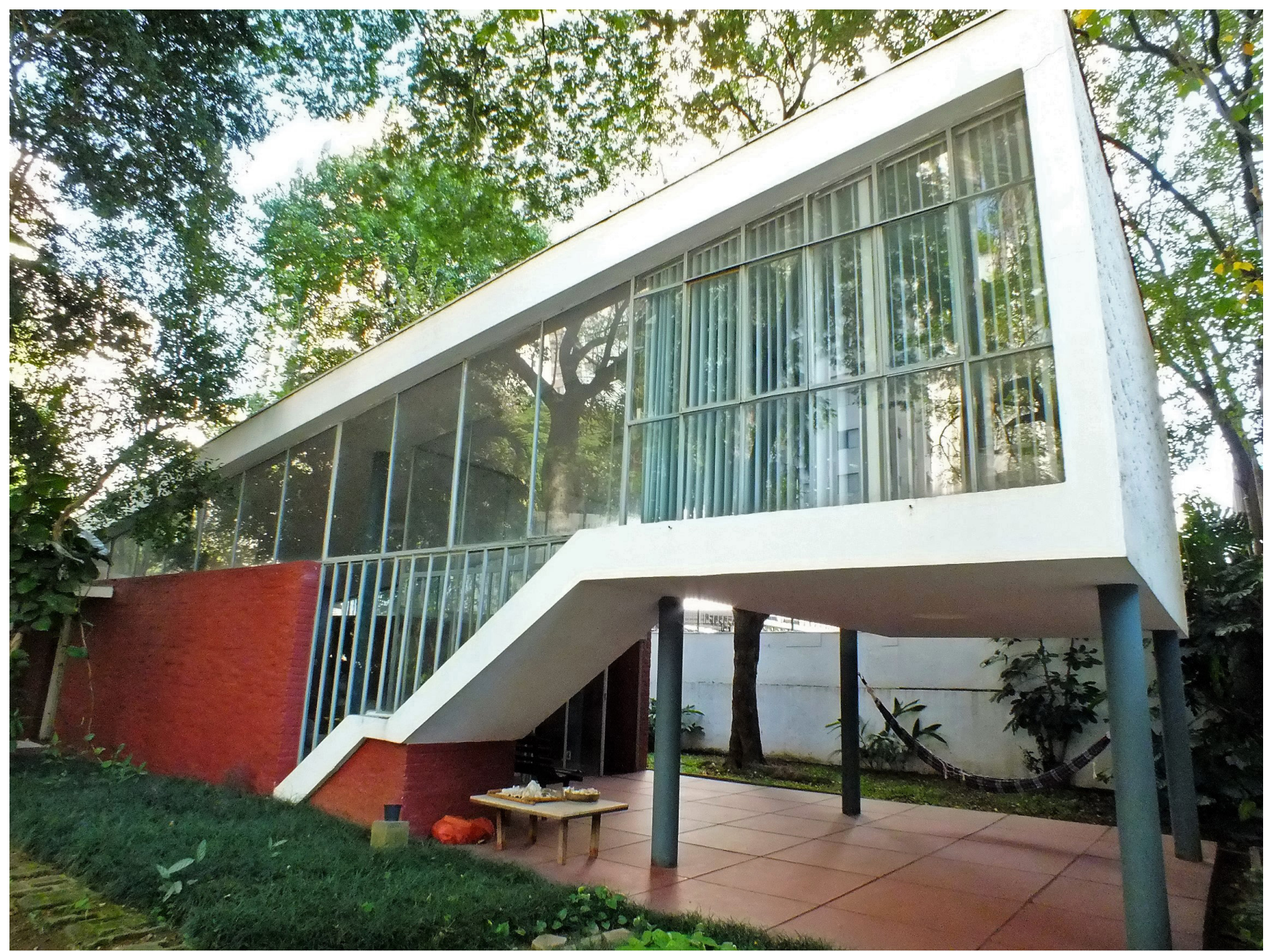



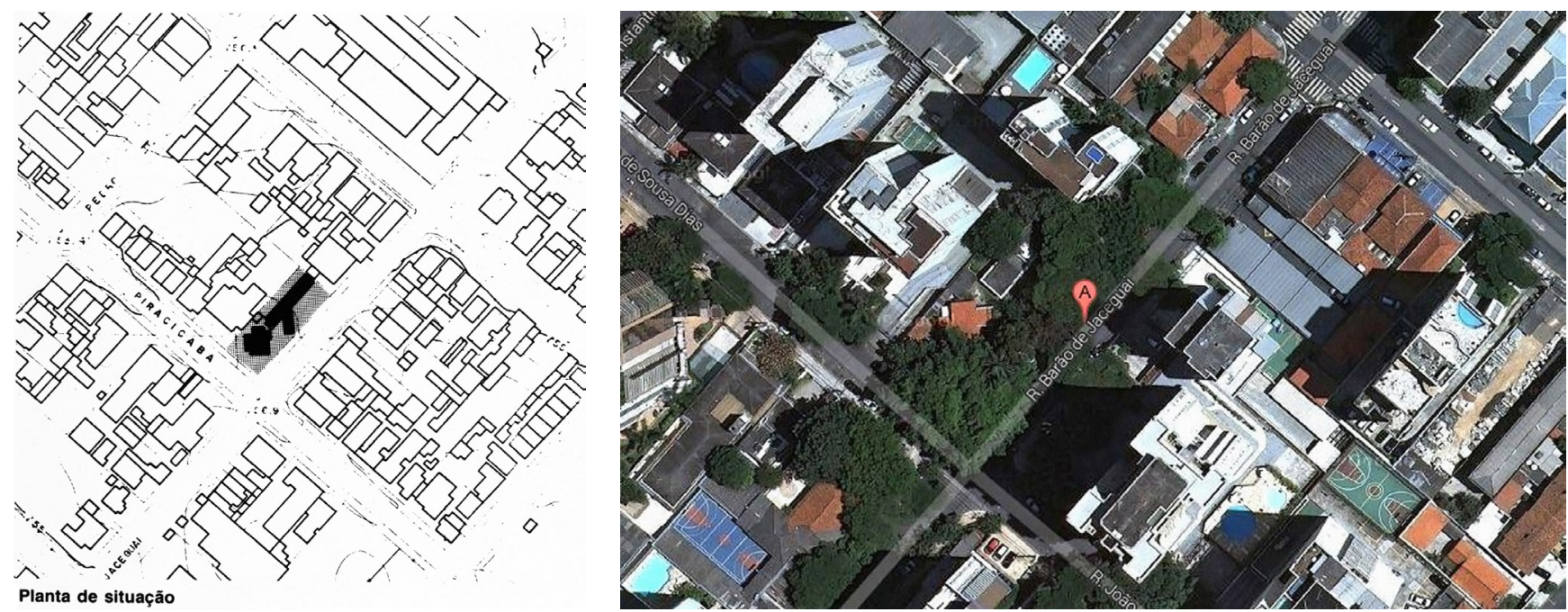

Figuras 22 e 23: Implantação e localização da residência. Fonte: ACAYABA,São Paulo, 1986, p36, e Google Maps.

2 Observações: Algumas instalações elétricas foram acrescidas e refeitas e as esquadrias dos quartos foram substituídas, porém a linguagem arquitetônica, cores e dimensões foram respeitadas. As duas residências fazem parte do conjunto arquitetônico tombado que esta à venda.
Dados da construção e estado atual

Construção: entre 1948 e 1949

Localização: Rua Barão de Jaceguai, 1151. Campo Belo, São Paulo.

Proprietário: Júlio Artigas

Área do terreno: $900 \mathrm{~m}^{2}$

Área construída: $208,27 \mathrm{~m}^{2}$

Área ocupada: 208,27m²

Estado Atual:2 O proprietário Júlio Artigas e sua esposa residem no imóvel. Está em excelente estado de conservação, tudo está preservado de acordo o projeto inicial, mesmo o mobiliário é muito próximo ao original.

\section{Análise gráfica}

Implantação, planta e corte

Como na análise anterior o primeiro ponto a ser analisado são plantas e cortes em si, onde se lê planta do subsolo, na verdade é o pavimento elevado que abriga o estúdio, esse erro foi mantido pois é assim que está a imagem de referencia.

"A intenção de Artigas em tal casa está voltada, principalmente, para a elaboração do volume formado por uma longa laje inclinada, gerando uma forma trapezoidal. Quanto aos eixos de composição são estes, um sua maioria transversais, compartimentando espaços cujo programa de necessidades tem simplicidade como característica. Com a distribuição das duas casas no mesmo terreno, temos um ponto interessante para ser analisado. sendo elaborados pelo mesmo arquiteto (com uma defasagem de seis anos), ambas contendo programas parecidos, apresentam dialética formal, deixando clara as alterações compositivas do arquiteto, num prazo exíguo de tempo. " (MIGUEL,2003)

Preservou-se a área verde ao redor da construção, adotando-se um volume principal ortogonal e alinhado com os limites do lote. Coloca os serviços novamente na área central, equidistante das extremidades, pois agora entendemos que Artigas retrabalha a forma quadrada por meio de um grande retângulo composto por uma sequencia de quadrados. O espaço principal com amplos curtain walls e pé-direito elevado, assim como no projeto anterior, a planta possui uma geometria pouco usual que remete novamente a implantação em diagonal de $45^{\circ}$. Aqui podemos uma ressonância das casas usonian diagonal de Frank Lloyd Wright (FUJIOKA, São Paulo, 2003, p. 106), porém agora na garagem, um espaço que não era relevante no projeto anterior agora ganha lugar de destaque ao ser a primeira interface entre a residência e a rua. 

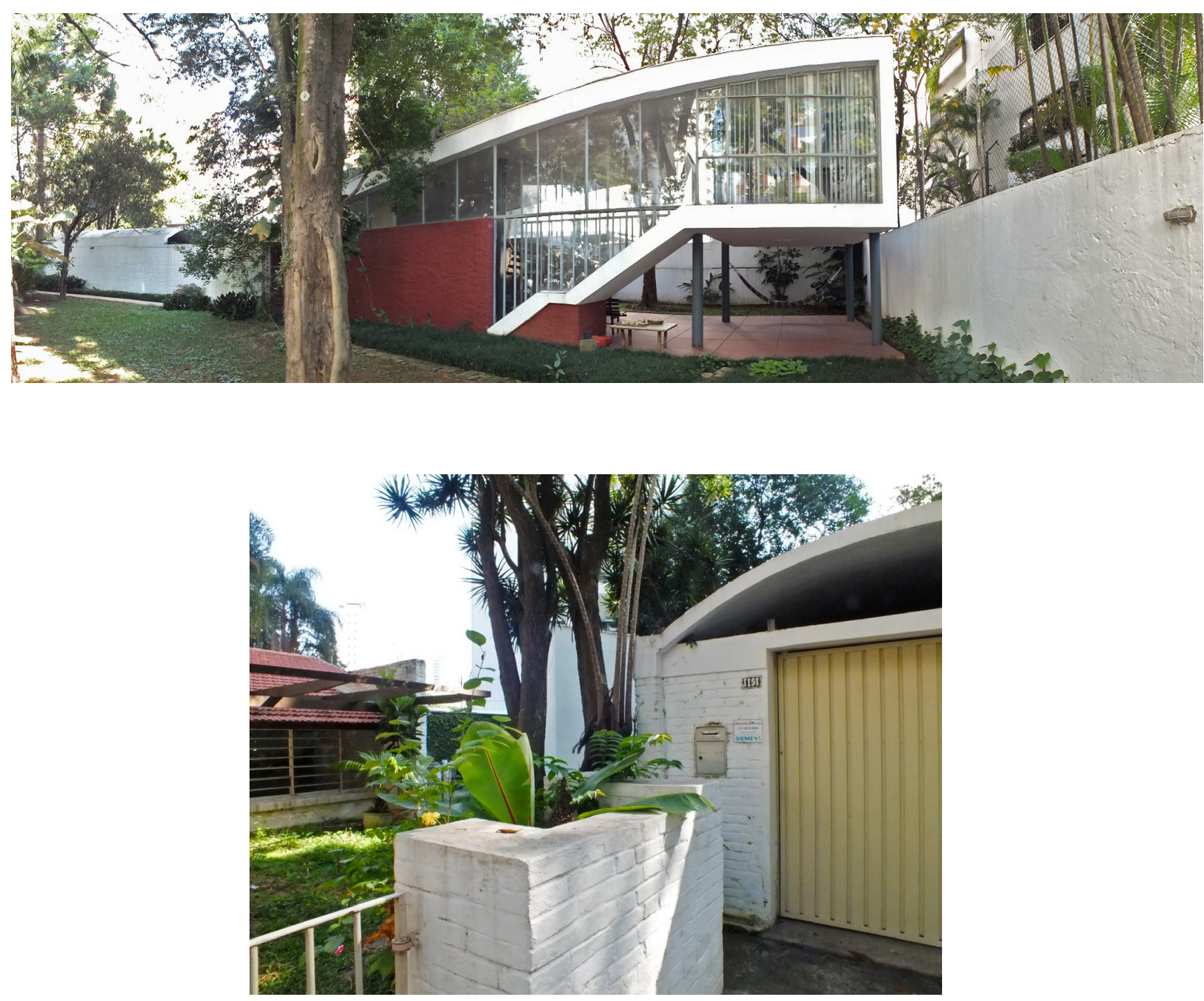

Figura 24 (topo): Casa do Arquiteto II e jardim. Fonte: acervo da autora.

Figuras 25 e 26: Relação entre as casas e interior da Casa do Arquiteto II. Fonte: acervo da autora.

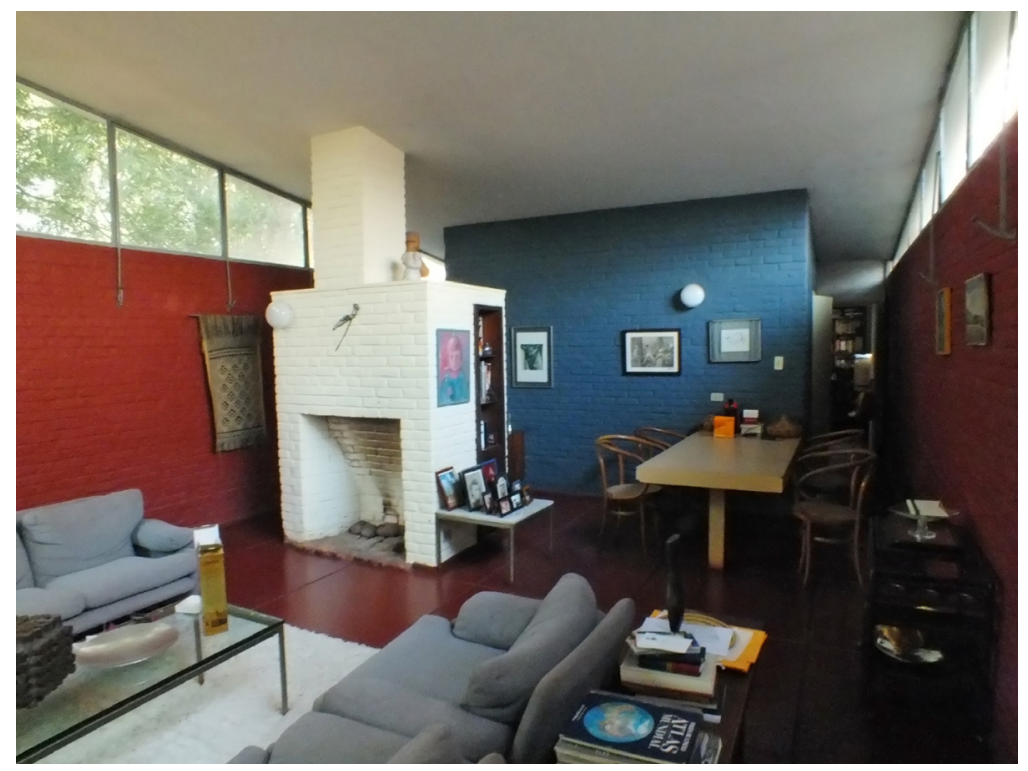



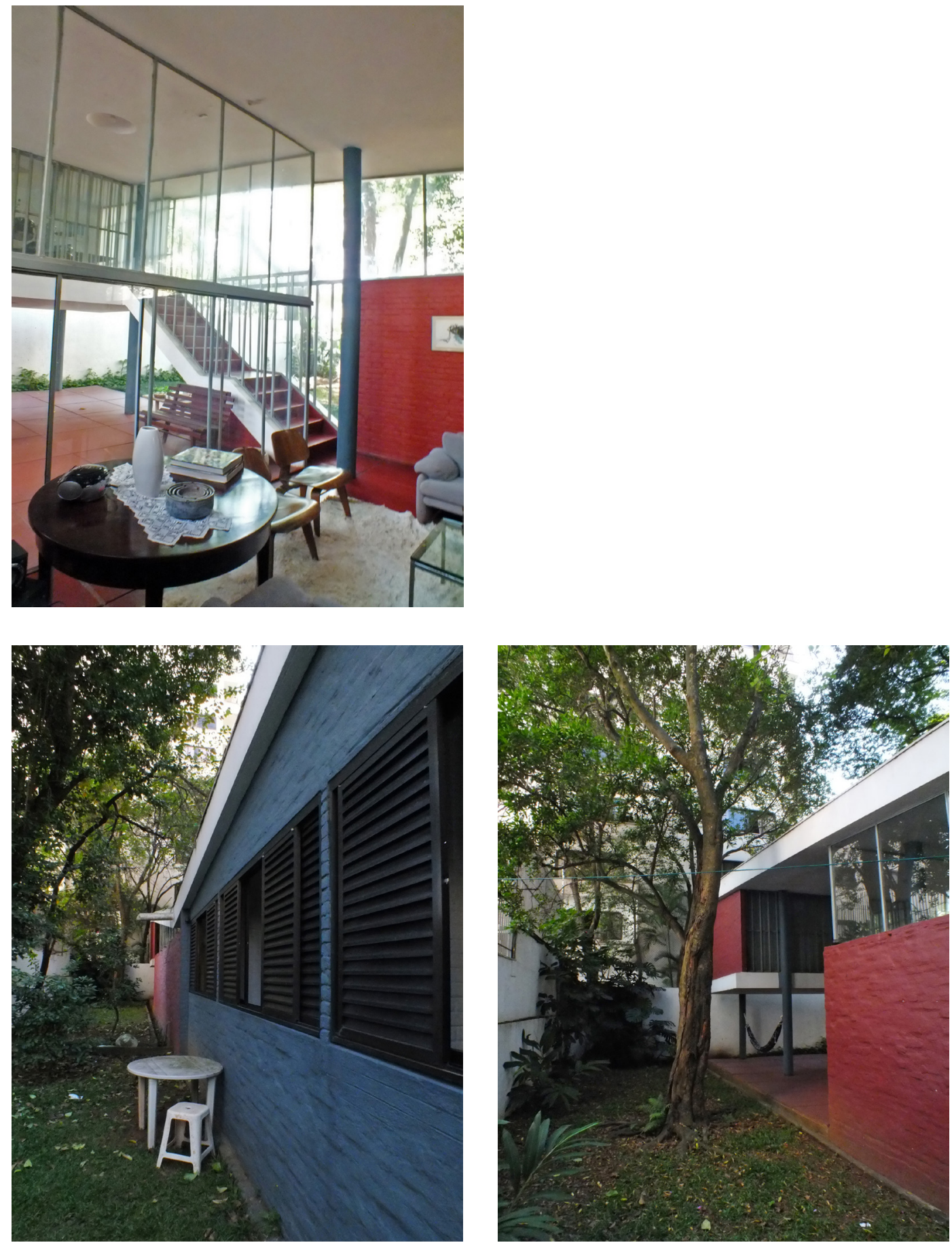

Figuras 27 a 29: Interior com móveis originais, esquadrias substituídas e jardim dos fundos. Fonte: acervo da autora. 
Figuras 30 e 31: Planta de ambos os pavimentos e corte esquemático longitudinal. Fonte: ACAYABA,São Paulo, 1986, p38.
Para tornar possível a coexistência dos dois projetos, o volume principal da segunda casa, um bloco linear cuja elevação formal apresenta um perfil muito próximo ao da residência Bittencourt, foi assentado em paralelo à rua e mais próximo da divisa dos fundos do lote. No amplo recuo frontal criado, o arquiteto dispôs uma pequena construção destinada a abrigar a garagem, a área de serviço e a entrada da casa, acoplada em angulo com o volume principal da moradia. A disposição enviesada desta construção secundária determina um acesso comum para as duas obras, ao mesmo tempo que faz uma referencia a implantação da casinha, construída a 45 graus em relação ao limite do terreno. Note-se como esta pequena construção frontal ainda funciona como um elemento de transição entre uma arquitetura e outra. (TENÓRIO, 2003. pp 126.)

É importante destacar duas características importantes do lote, podendo-se dizer que é uma força do lugar (BAKER, 1998), que são fundamentais a compreensão do projeto. O terreno é naturalmente plano, o que permite uma visada única para as duas residências ao olhá-las do perfil do arruamento e também por ser um lote de esquina, o que permitiu que ambas edificações possuíssem múltiplos acessos.

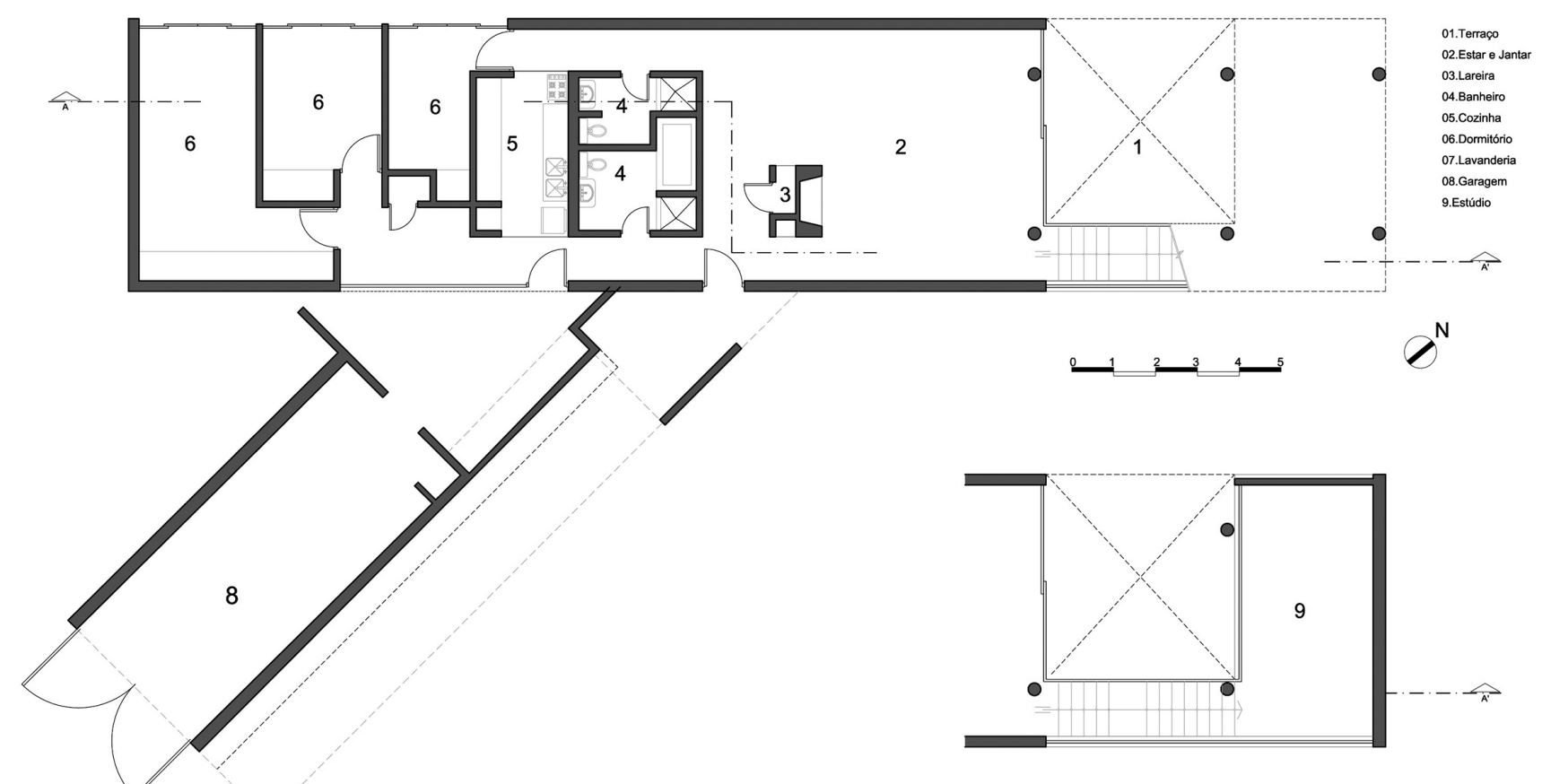

Planta Térreo

Planta Estúdio

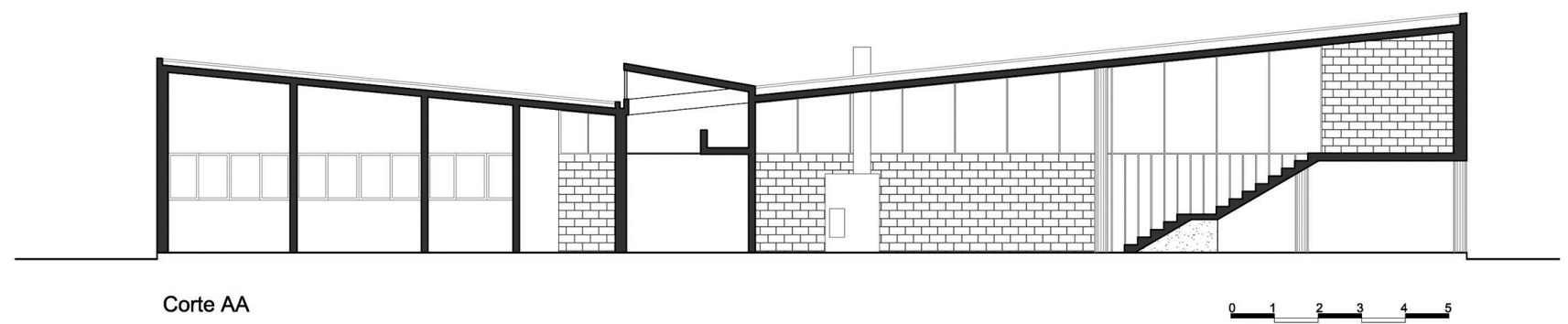



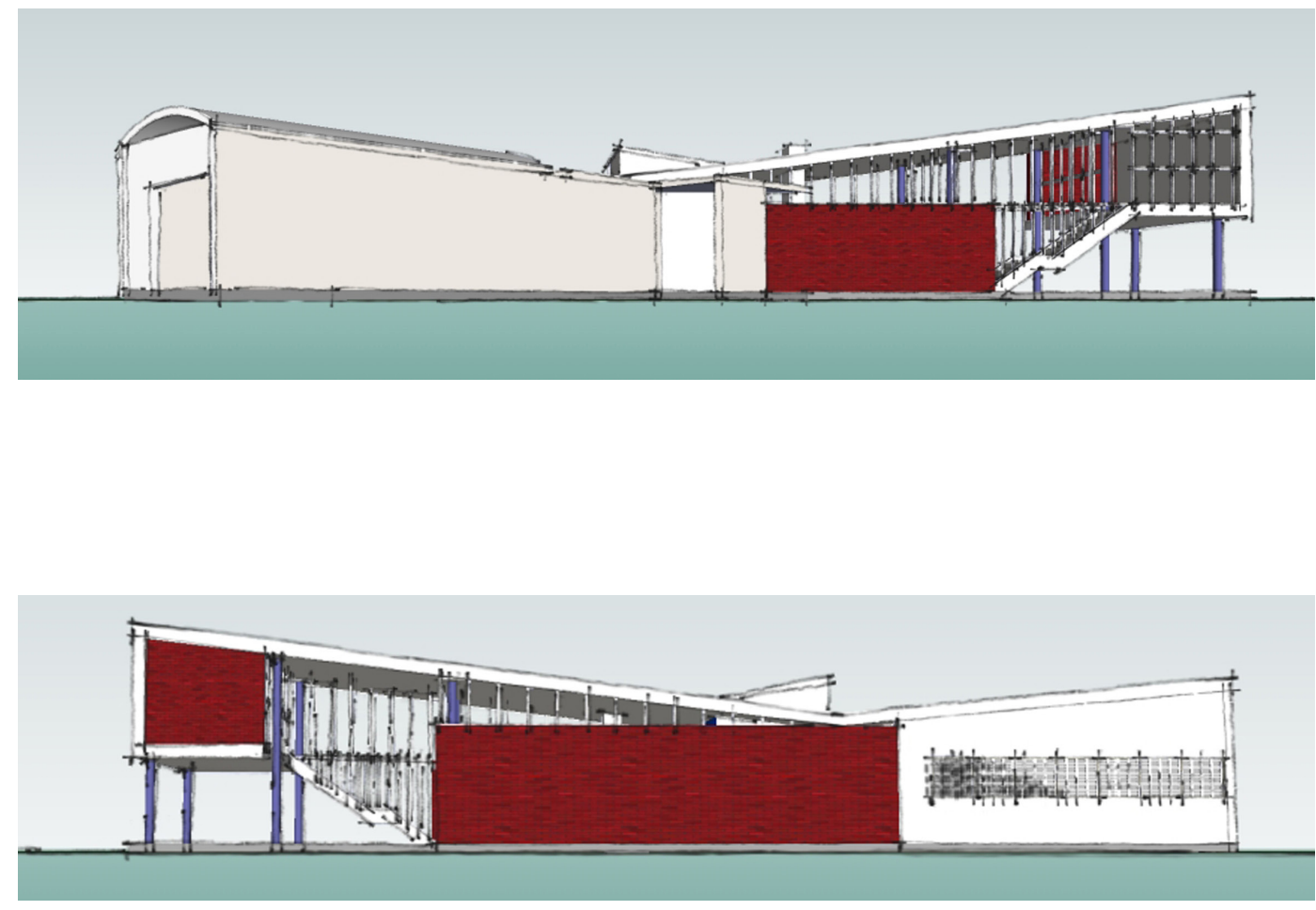

Figura 32 (topo): Elevação frontal, modelo eletrônico Fonte: modelo produzido pela autora.

Figura 33 (meio): Elevação fundos, modelo eletrônico Fonte: modelo produzido pela autora.

Figuras 34 e 35 (embaixo): Elevações laterais, modelo eletrônico. Fonte: modelo produzido pela autora.

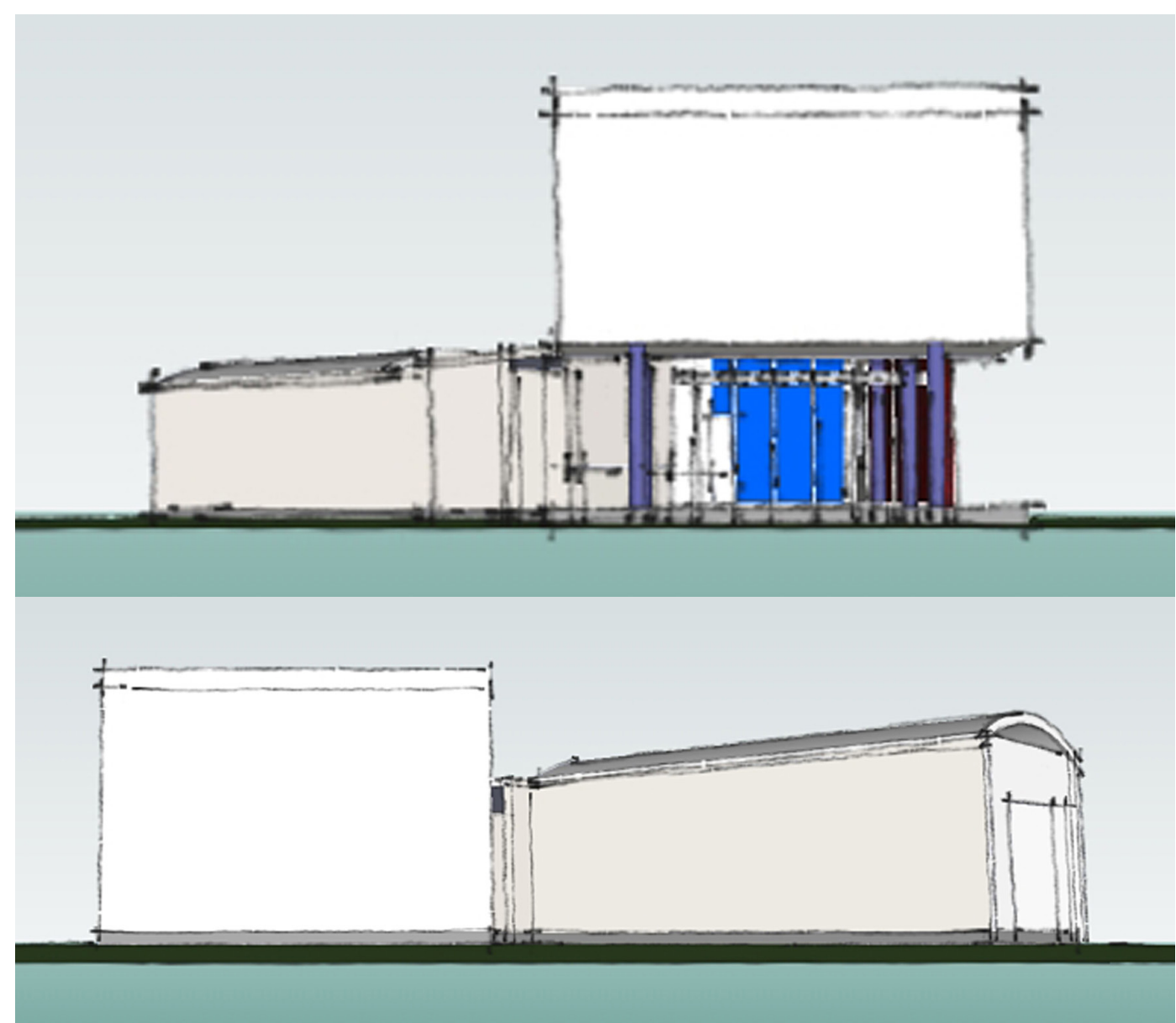


Figuras 36 e 37: Detalhes de estrutura Fonte: acervo da autora.
Programa, circulação, iluminação e estrutura

O programa da nova residência, agora para uma família de quatro pessoas, continua enxuto, acrescentando-se mais dormitórios e sanitários. A relação programa / circulação é resolvida de forma ordenada e funcional, concentrando-se a circulação em dois corredores que faceiam o volume, desembocando nas áreas sociais. Com isso, pode-se colocar a hipótese de que a circulação governa funcionalmente a distribuição dos ambientes pelo fluxo; caminhando-se dos espaços abertos e contínuos para os restritos e fechados.

Assim como especulamos que iluminação e estrutura fizeram parte de um mesmo momento de concepção projetual, pois os pilaretes da área social e de trabalho que sustentam juntamente com a estrutura em concreto o delicado telhado borboleta, possibilitando que haja vedação em tijolo no núcleo intimo e painéis envidraçados que iluminam hora zenitalmente hora completamente os ambientes sociais.
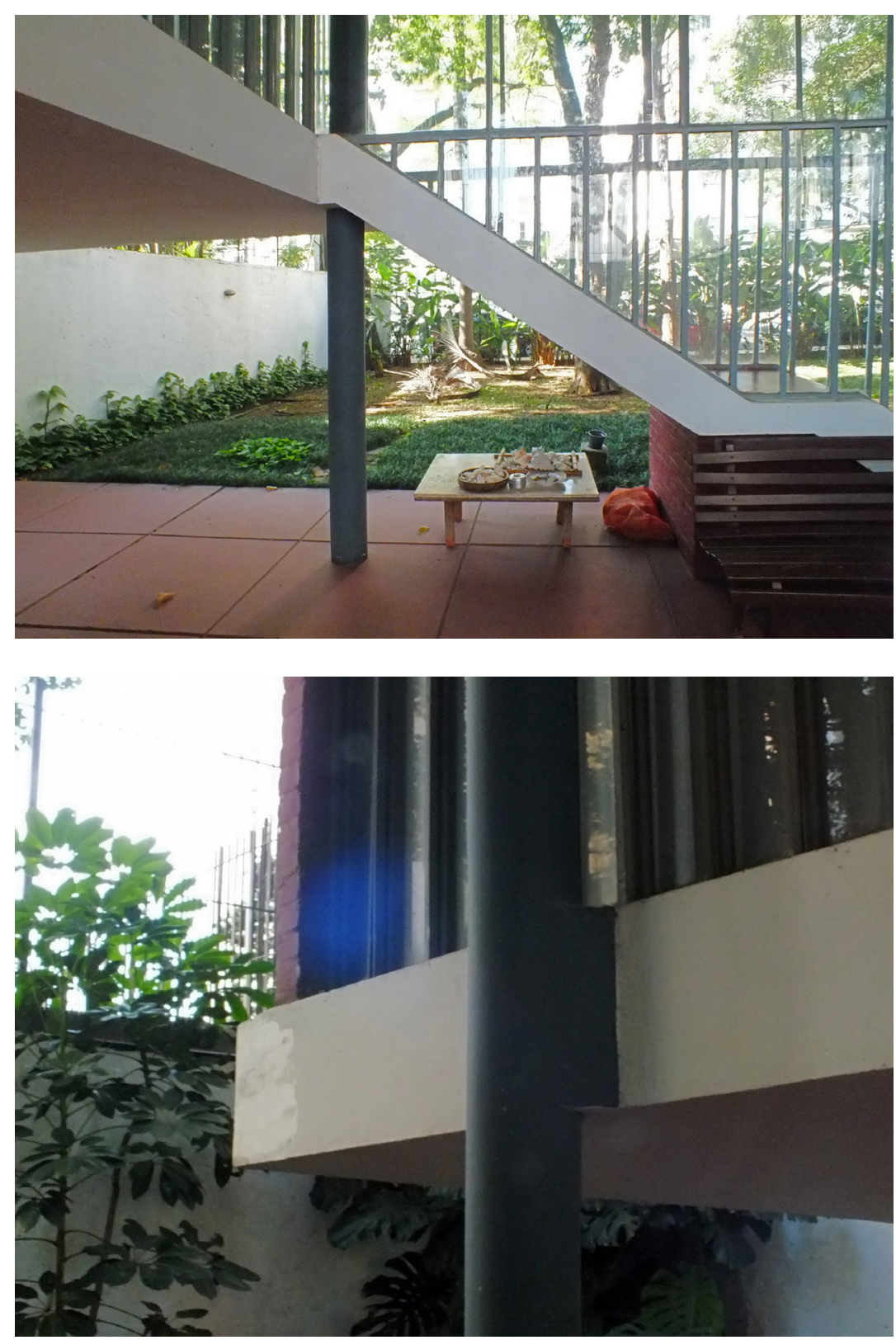


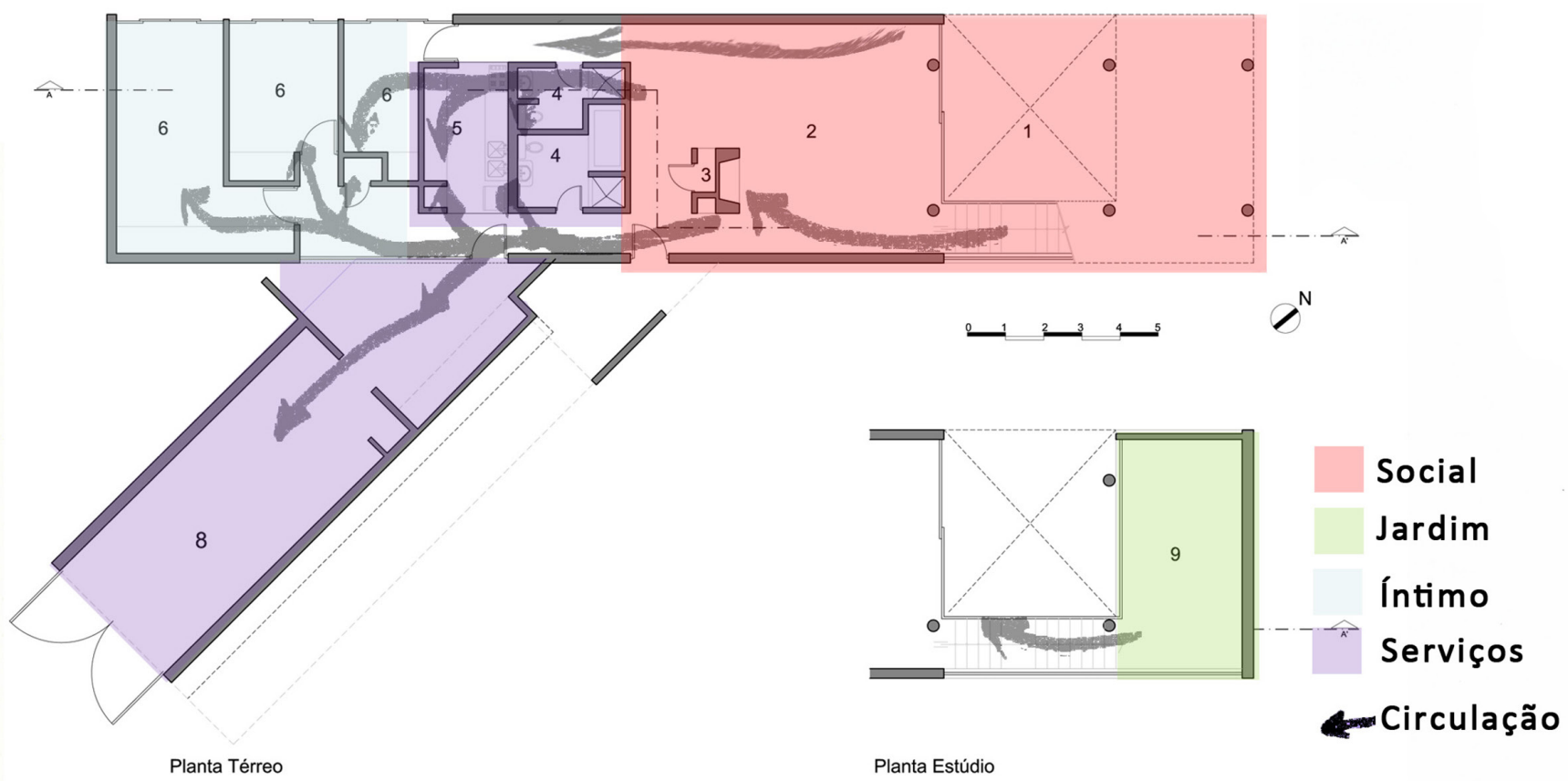

Figura 38 (topo): Relações gráficas 2D de programa e circulação. Fonte: intervenção sob imagem ACAYABA,São Paulo,1986, p38.

Figuras 39 e 40: Relações gráficas 3D de programa e circulação. Fonte: modelo produzido pela autora.

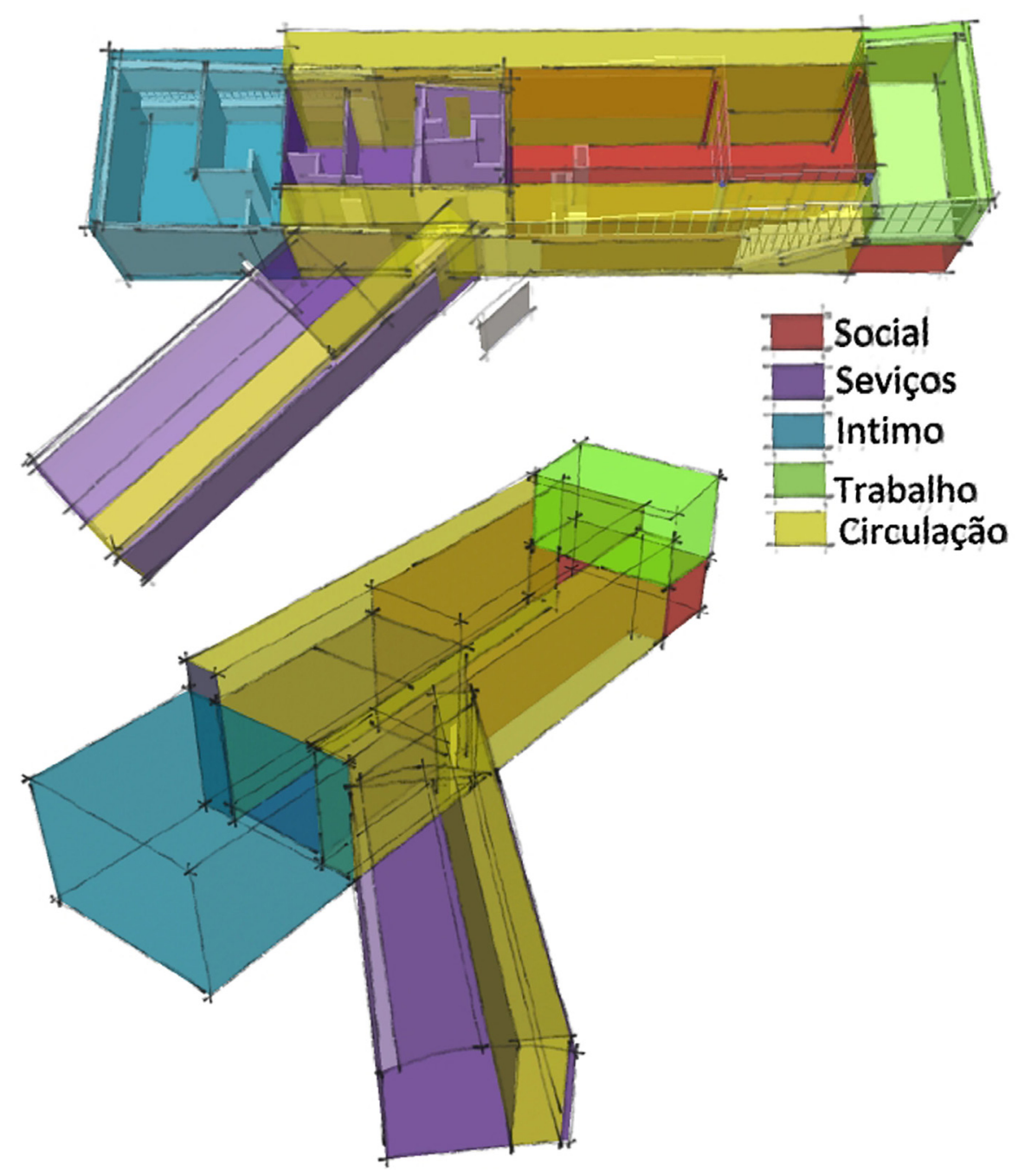




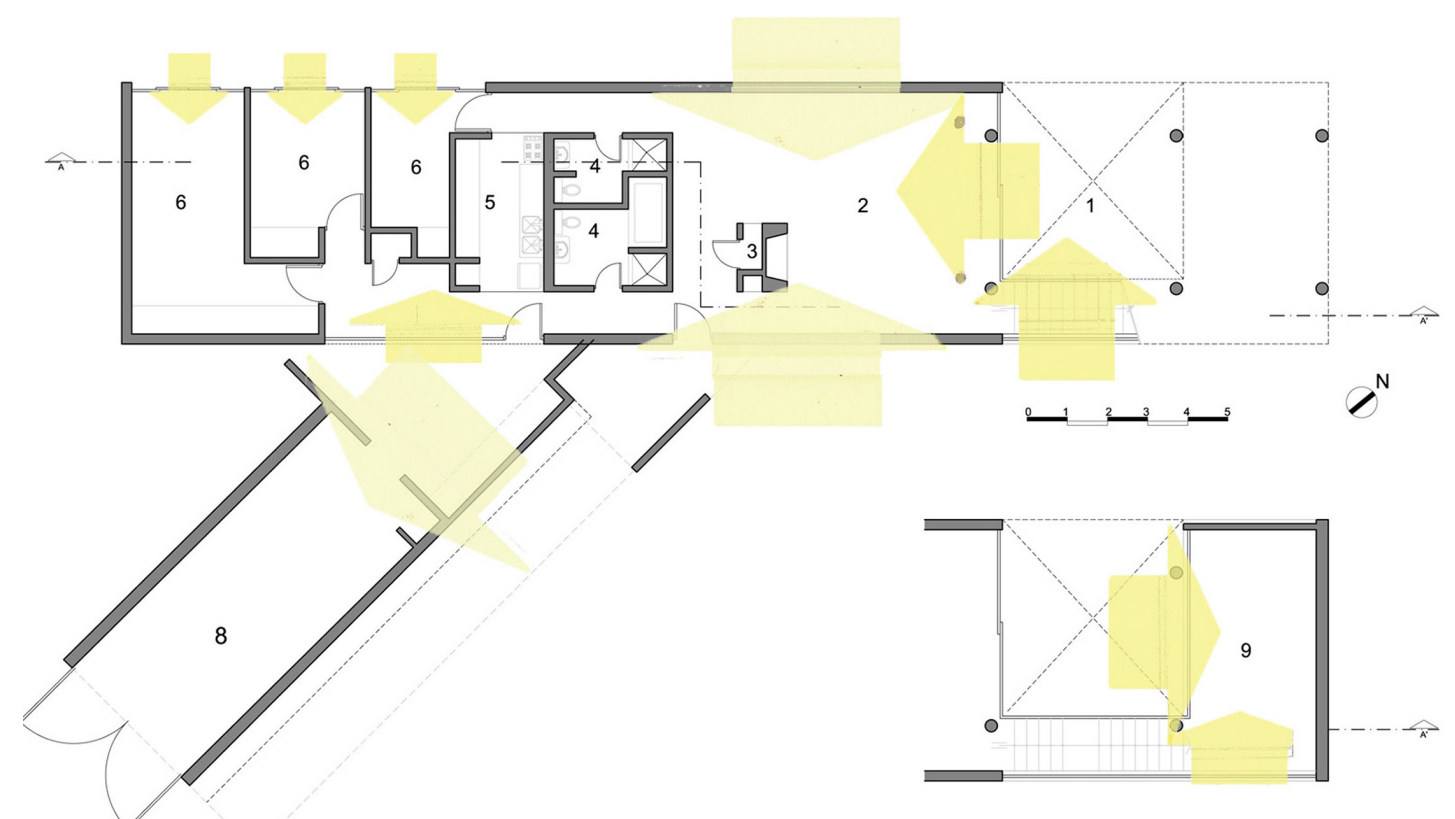

Figura 41 (topo): Relações gráficas 2D de iluminação e estrutura. Fonte: intervenção sobre imagem de ACAYABA, São Paulo, 1986, p38.

Figuras 42 a 44: Relações gráficas 3D de iluminação, programa e estrutura. Fonte: modelo produzido pela autora.
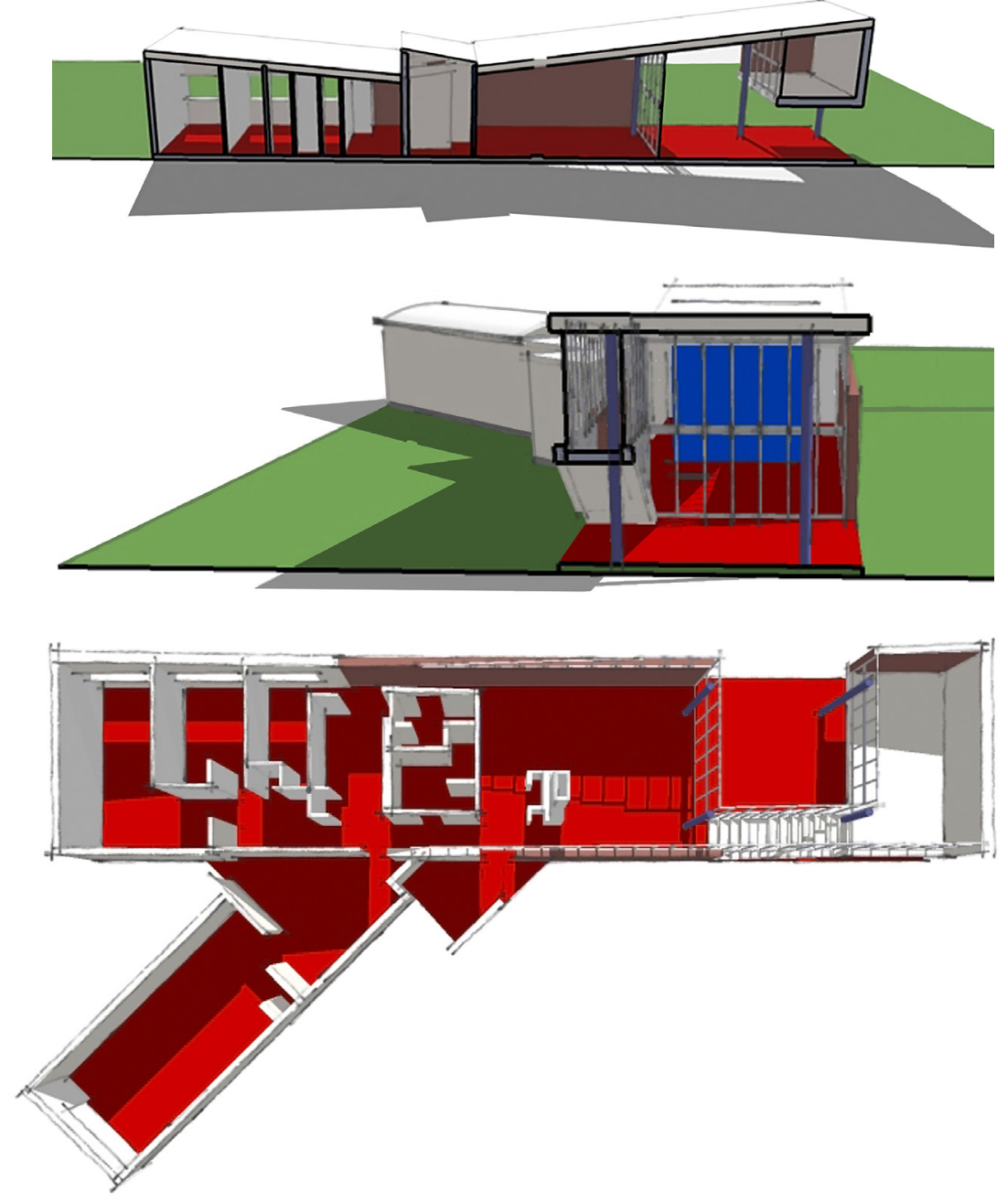
Figura 45: Relações gráficas 2D de traçado regulador, proporções, rotação de volume. Fonte: intervenção sobre imagem de ACAYABA,São Paulo, 1986, p38.

Figura 46: Relações gráficas 2D em corte de traçado regulador e proporções. Fonte: intervenção sobre imagem de ACAYABA, São Paulo, 1986, p38.
Geometria ideal, proporção e equilíbrio

Apesar de apresentar menos relações que a casinha, possivelmente pela alteração de estrutura de planta, por trabalhar com áreas maiores em uma geometria alongada, ainda guarda relações interessantes entre os elementos. Entendemos aqui que Artigas também baseia esse projeto na justaposição de quadrados de diferentes dimensões, tanto em planta quando em corte, porém no corte existe uma progressão crescente das formas empregadas.

A hipótese aqui adotada é de que a forma geradora da planta é o quadrado, entretanto o agrupamento deles se mostra como retângulo, inclusive um em proporção áurea nas áreas sociais e de trabalho, situação próxima à criada no projeto anterior da Casinha. Sendo assim, um novo elemento é encontrado na análise volumétrica, todo o projeto é regido pelo agrupamento de cubos.

Logo, concluímos que um possível partido de projeto para essa residência é similar ao da casinha, onde o a forma cubica e elemento gerador e os ângulos reto e de $45^{\circ}$ são os mais utilizados na composição, então embora elas sejam bastante diferentes no uso dos materiais e na forma os princípios de composição de projeto seu partido gerador é muito similar.
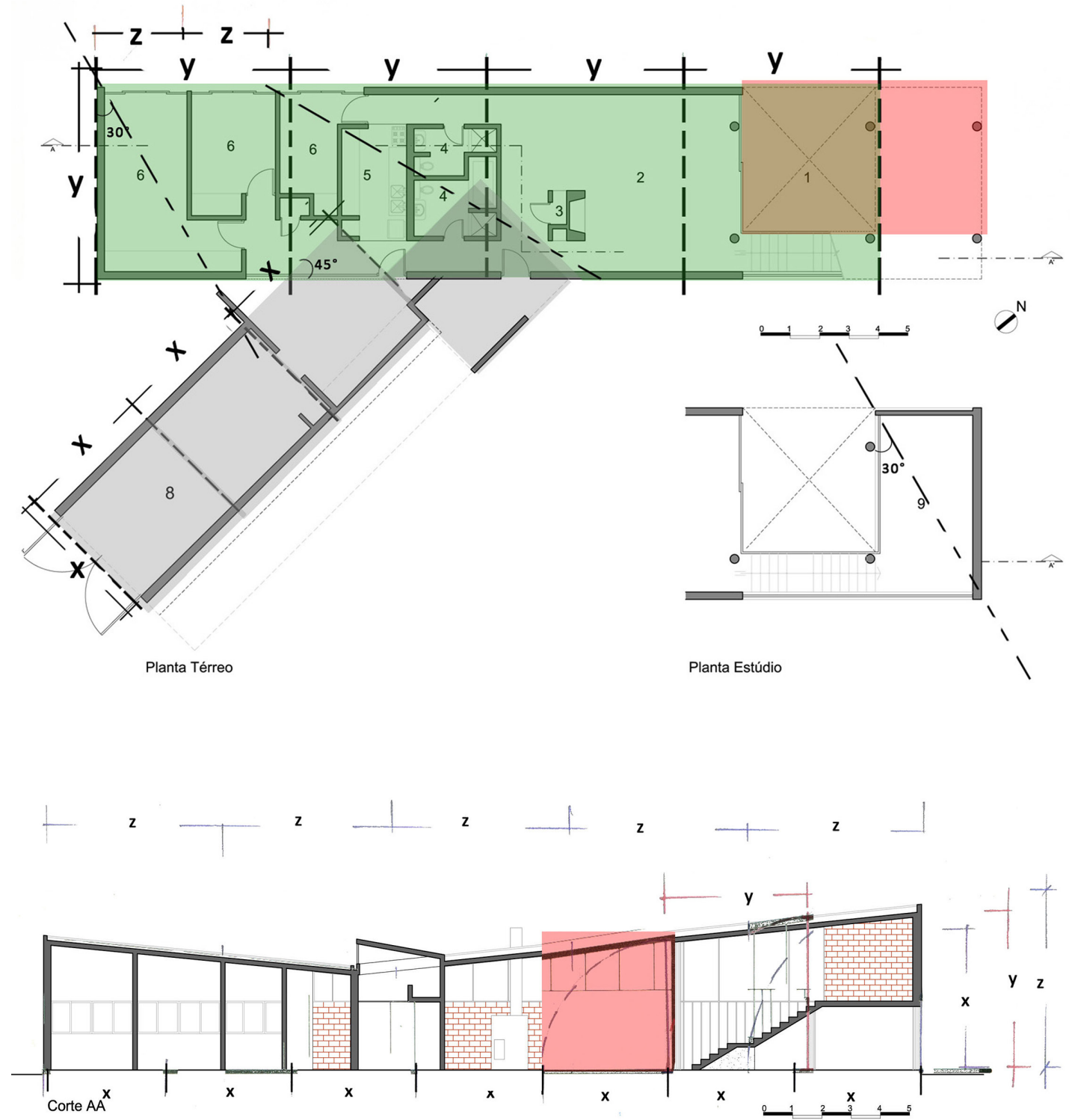


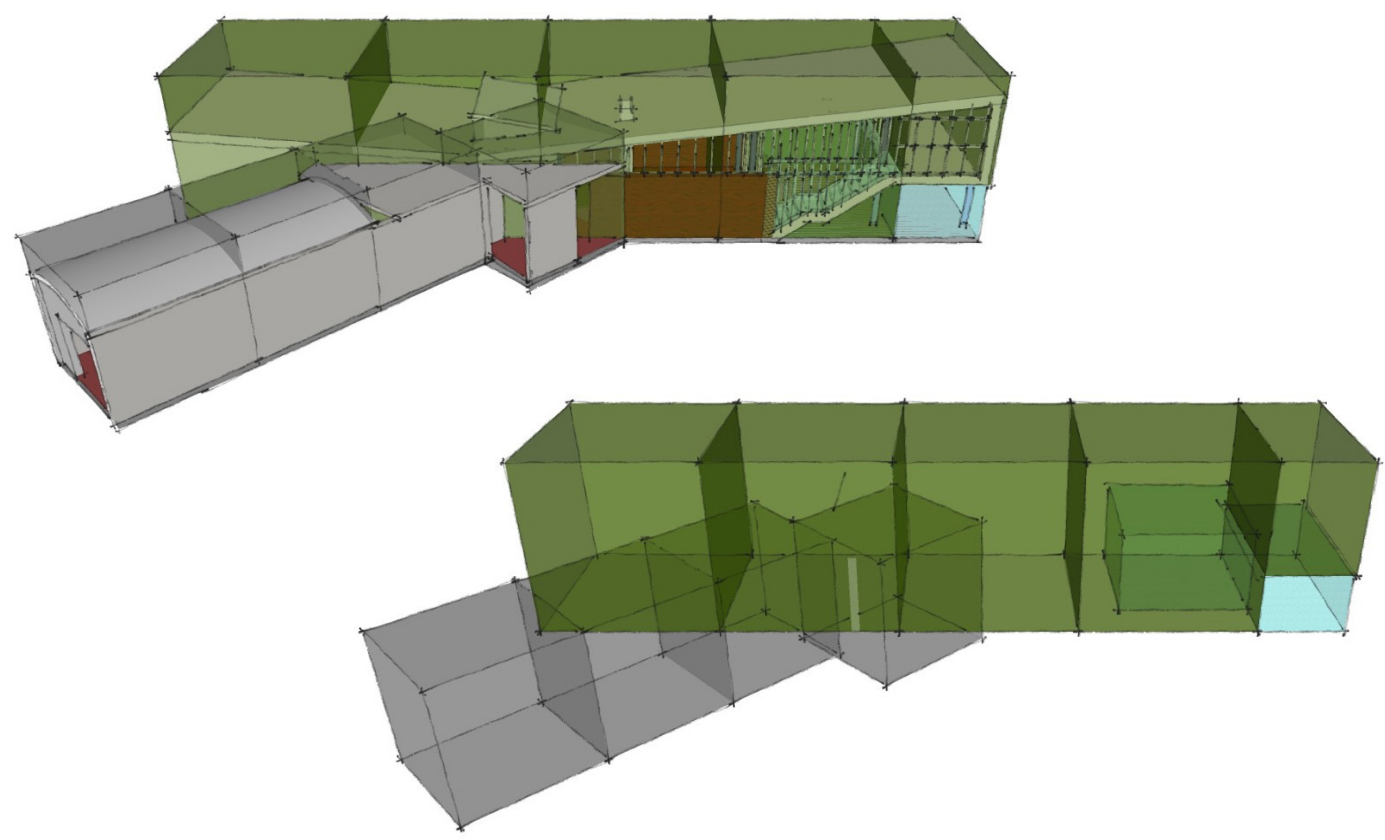

Figura 47 (topo): Análise 3D de relações gráficas de proporções e articulação de volumes. Fonte: modelo produzido pela autora.

Figura 48: Análise 3D de proporções e relações volumétricas. Fonte: modelo produzido pela autora.

\section{Conclusão}

A forma, partido e materialidade das casas do arquiteto são resultado de soluções de projeto que refletem uma visão pessoal - que abrange um universo de escolhas que vão da arquitetura residencial preferida à dimensão lírica das memórias de sua intimidade. Questões ideológicas, estéticas e construtivas se envolvem nessa visão pessoal durante o processo de projeto. Nesse trabalho buscamos hipóteses e especulações sobre esse processo baseados nas peças gráficas existentes e nos relatos encontrados em textos e escritos do e sobre o arquiteto.

Ao analisarmos o projeto acabado, tanto em peças gráficas quanto em volumetria, é possível especular sobre as decisões de composição formal que levaram àquele resultado espacial, estabelecendo uma hipótese de processo projetual das obras estudadas. Além disso, podemos observar o projeto arquitetônico como artefato de análise estética em si, como obra autônoma e não apenas um conjunto de diretrizes para a construção do objeto real.

A "Casinha" possui um significado simbólico muito grande, uma vez que foi mostrou uma possível uma alternativa de casa unifamiliar, distinta da casa paulistana do Ecletismo da época e dos valores da clientela tradicional, que Artigas questionava. Em contrapartida, na segunda casa, parte de um conjunto de experiências distintas na segunda fase de sua carreira, é possível notar a proposição de formas e espaços alusivos a Bratke e Le Corbusier, tais como a cobertura borboleta, o espaço fluido e aberto do salão com ampla fenestração, a estrutura independente e caixa de vidro da escada configurando uma promenade architecturale, a cobertura da garagem reminiscente da abóbada catalã, a laje de cobertura formando com a parede e a laje do estúdio uma moldura. Na escada, no terraço e no salão podemos ver o arquiteto experimentando elementos de um partido arquitetônico que atingirá sua maturidade na Casa Tacques Bittencourt II (1959).

Tanto a "Casinha" quanto a "Casa do Arquiteto II" demonstraram-se bastante fecundos no estudo de composição de projeto uma vez que demonstram os anseios de um jovem arquiteto, refletindo as transformações radicais no campo da arquitetura, da arte, do pensamento, no turbilhão das revoluções e guerras da primeira metade do século XX. Nestas singelas casas podermos observar a travessia de Artigas da primeira para a segunda fase, já presentes várias das características de partido e expressão construtiva que podem ser vistas, consolidadas, na maturidade da terceira fase de sua obra. 


\section{Referências bibliográficas}

ARTIGAS, Vilanova. Caminhos da Arquitetura.org José Tavares Correa de Lira Rosa Artigas. São Paulo, Cosac Naify, 2004.

ACAYABA, Marlene Milan. Residências em São Paulo 1947-1975. São Paulo: Projeto Editores Associados / Eucatex, 1986

BAKER, Geoffrey H. Le Corbusier - Uma Análise da Forma. São Paulo: Livraria Martins Fontes Editora, 1998.

BRUAND, Yves. Arquitetura contemporânea no Brasil. Rio de Janeiro: Perspectiva, 1980

BERREDO, Hilton e LASSANCE, Guilherme. Análise gráfica, uma questão de síntese - A hermenêutica no atelier de projeto. Arquitextos 133.01 in Vitruvius Arquitextos 133 ano 12 Junho 2011

BUZZAR, Miguel Antonio. João Vilanova Artigas: elementos para a compreensão de um caminho da arquitetura brasileira, 1938-1967. São Paulo:Editora Senac, 2014.

CONWAY, Hazel e ROENISCH, Rowan. Understanding Architecture - An introduction to Architecture and Architectural History. Londres: Routledge, 2011.

CLARK, Roger H. e PAUSE, Michael. Precedents In Architecture - Analytic Diagrams, Formative Ideas, and Partis. Hoboken: John Wiley and Sons, 2005.

CUNHA, Gabriel Rodrigues. Uma análise da produção de Vilanova Artigas entre os anos de 1967 a 1976. 2009. 200f. Dissertação (Mestrado - Programa de Pós-Graduação em Arquitetura e Urbanismo e Área de Concentração em Teoria e Historia da Arquitetura e do Urbanismo) - Escola de Engenharia de São Carlos da Universidade de São Paulo, São Carlos.

CUNHA, Marcio Cotrim. A casinha de Artigas: reflexos e transitoriedade. Arquitextos 133.01 in Vitruvius Arquitextos 061 ano 01 Junho 2005

EDWARDS, Brian. Understanding Architecture through drawing. Londres: Routledge, 2011.

FERRAZ, Marcelo et. alli. (orgs.). Vilanova Artigas. São Paulo: Instituto Lina Bo e Pietro Maria Bardi, 1997.

FONSECA, Benício Geraldo da. Representação gráfica de arquitetura entre continuidade e inovação. Arquitextos 132.04 in Vitruvius Arquitextos 132 ano 11 Maio 2011

FUJIOKA, Paulo Yassuhide. O Edifício Itália e a arquitetura dos edifícios de escritórios em São Paulo. Dissertação de Mestrado. São Paulo: FAU-USP, 1996
FUJIOKA, Paulo Yassuhide. Princípios da Arquitetura de Frank Lloyd Wright e suas influências na Arquitetura Moderna Paulistana. Tese de Doutorado. São Paulo: FAU-USP, 2004.

IRIGOYEN, Adriana M. Wright e Artigas: Duas Viagens. São Paulo: Ateliê Editorial-FAPESP, 2002

KAMITA, João Massao. Vilanova Artigas. São Paulo: Cosac \& Naify, 2000

MEDRANO, Leandro Silva e RECAMAN, Luiz. Vilanova Artigas. Habitação e cidade na modernização brasileira. Campinas: Editora da Unicamp, 2013

MINDLIN, Henrique E. Arquitetura Moderna no Brasil. Rio de Janeiro: Editora Aeroplano, 1999

MIGUEL, Jorge Marão Carnielo. A Casa. Londrina:Eduel São Paulo: Imprensa Oficial do Estado de São Paulo, 2003

RIBEIRO,Abilio G e CASTROVIEJO, Alessandro J. Casas brasileiras do século XX. Arquitextos 074 in Vitruvius ano 05, julho 2006

SAHM, Estela (coord.). Os Desenhos da Arquitetura. Catálogo de exposição. Textos de Carlos A.F. Martins, Fernando Vazquez y Ramos, Renato L.S. Anelli. São Carlos-SP: EESC-USP / SAP, 1995.

SEGAWA, Hugo. Arquiteturas no Brasil 1900-1990. São Paulo: ProEditores, 1999

TENÓRIO, Alexandre de Souza. Casas de Vilanova Artigas. 2003. 207f. Dissertação (Mestrado Programa de Pós-Graduação em Arquitetura e Urbanismo e Área de Concentração em Tecnologia do Ambiente Construido) - Escola de Engenharia de São Carlos da Universidade de São Paulo, São Carlos.

THOMAS, Dalva. E. Vilanova Artigas - Desenhar é preciso viver também é preciso. in revista AU-Arquitetura e Urbanismo no. 50, Outubro/Novembro 1993. São Paulo: Editora Pini.

UNWIN, Simon. Análise da Arquitetura tradução: Alexandre Salvaterra. Porto Alegre: Bookman, 2013.

Warchavchik, Gregori. Arquitetura do século XX e outros escritos. São Paulo Cosac Naify 2006.

XAVIER, Alberto (org.). Depoimentos de uma geração - Arquitetura Moderna Brasileira. São Paulo: CosacNaify, 2003

ZABALBEASCOA, Anatxu. The House of the Architect. Barcelona: Ed. Gustavo Gili, 1995 